Cornell University Law School

Scholarship@Cornell Law: A Digital Repository

6-23-2020

Recklessness, Intent, and War Crimes: Refining the Legal

Standard and Clarifying the Role of International Criminal

Tribunals as a Source of Customary International Law

Brian L. Cox

Follow this and additional works at: https://scholarship.law.cornell.edu/facpub

Part of the Courts Commons, International Humanitarian Law Commons, and the International Law Commons 


\title{
ARTICLES \\ RECKLESSNESS, INTENT, AND WAR CRIMES: REFINING THE LEGAL STANDARD AND CLARIFYING THE ROLE OF INTERNATIONAL CRIMINAL TRIBUNALS AS A SOURCE OF CUSTOMARY INTERNATIONAL LAW
}

\author{
BRIAN L. Cox*
}

\begin{abstract}
This Article explores the substantive and procedural aspects of the assertion that recklessness is included on the spectrum of mens rea for war crimes as a matter of customary international law. The substantive aspect of the inquiny, in Part I, engages in a critical assessment of the assertion that the jurisprudence of international criminal tribunals indicates that recklessness is sufficient to support a war crimes prosecution in general. The procedural aspect, in Part II, contests the prevailing "principal-agent" construct of describing the relationship between states and international criminal tribunals and the resulting role of tribunals in establishing customary international law. After rejecting the prevailing construct, the Article introduces the "designate and extend" model to clarify the relationship between states and international criminal tribunals.

The substantive inquiry in Part I demonstrates that the jurisprudence of international criminal tribunals does indicate that recklessness is included on the mens rea spectrum for war crimes, but only in specific, limited conditions. The procedural inquiny in Part II, while applying the new designate and extend model, confirms the role of decisions by international criminal tribunals as a
\end{abstract}

\footnotetext{
* Brian L. Cox is an adjunct professor of law at Cornell Law School and a visiting scholar at Queen's Law in Ontario. Professor Cox retired in 2018 from the U.S. Army after 22 years of military service. He served as an airborne infantry soldier, combat camera operator, airborne infantry officer, and for seven years as a military legal advisor. His combat deployments include Iraq from 2003-2004 as a combat camera operator and Afghanistan from 2013-2014 as an operational law advisor and the chief of international and operational law for Regional Command-East. Professor Cox also served as a military prosecutor, federal prosecutor, brigade judge advocate, and military magistrate while he was a military legal advisor. His military awards, decorations, and qualifications include the Ranger Tab, Senior Parachutist Badge, Pathfinder Badge, Air Assault Badge, Bronze Star Medal, Meritorious Service Medal, NATO Medal, Basic and Advanced Collateral Damage Estimation Certification, and Joint Firepower Certification. Professor Cox holds an LL.M. from Queen's Law and a B.A. (International Relations) and J.D. from the University of North Carolina. $\subset$ 2021, Brian L. Cox.
} 
subsidiary-rather than primary-source of customary international law. The substantive aspect of the inquiry addresses the specific issue of the spectrum of mens rea for war crimes in order to refine the existing legal standard, while the procedural aspect adopts a broader approach to clarify the general relationship between states and international criminal tribunals. Both inquiries address unsettled issues that are central to the theory and practice of public international law.

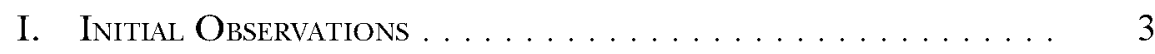

II. The Recklessness Assertion. . . . . . . . . . . . . . . . 6

III. Part One: Substantive Assessment of the Recklessness

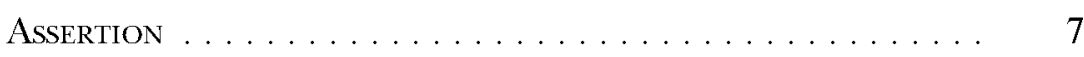

A. The Spectrum of Mens Rea ................. 8

B. ICTY Jurisprudence: Detainee Abuse and the Cited Delalic Decision ......................... 12

C. ICTY Jurisprudence: Joint Criminal Enterprise and Command Responsibility. . . . . . . . . . . . . . . . . 14

D. ICTY Jurisprudence: Targeting in Armed Conflict . . . . . . . 17

1. Galic and the Foundation for Recklessness in Targeting Civilians . . . . . . . . . . . . . 17

2. "Applying" the Galić Recklessness Test: ICTY Strugar and Perišć Cases . . . . . . . . . . . . . . 27

E. Consolidating Recklessness and Mens Rea in ICTY Jurisprudence . . . . . . . . . . . . . . . . . . . . . . . . 29

F. "International Case-Law" and the International Criminal Court........................ 32

G. Consolidating the Substantive Aspect . . . . . . . . . . . 45

IV. Part Two: Procedural Assessment and the "Designate and Extend" Model . . . . . . . . . . . . . . . . . . . . . 47

A. Principal-Agent Method of Describing Relationship Between States and Tribunals ..................... 51

B. Designate and Extend Model of Describing Relationship Between States and Tribunals . . . . . . . . . . . . . . . 57

1. Establishing the Parameters of the Designate and Extend Model ................... 59

2. The Evolution of Statutes as Prescriptions in the Designate and Extend Model ........... 62

3. Consolidating the Designate and Extend Model: Distinguishing Between Statutes and Judicial

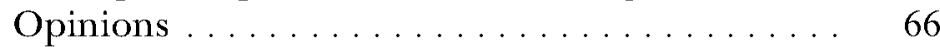

V. Concluding Reflections . . . . . . . . . . . . . . . . 68 


\section{Initial ObSERVATIONS}

"As you know, individuals who commit serious violations of the laws of war with criminal intent - that is, intentionally or recklessly-are responsible for war crimes." This observation was offered by Human Rights Watch to then-Secretary of Defense Ash Carter following the October 2015 attack on the Médecins Sans Frontières (MSF) trauma center in Kunduz City, Afghanistan, that tragically killed forty-two civilians, injured dozens more, and destroyed the MSF hospital. ${ }^{2}$ That recklessness is a sufficient mens rea to support a war crimes prosecution as a matter of customary international law is a common refrain in the theory and practice of international law. Is this recklessness assertion, however, deserving of the widespread acceptance it seems to have achieved?

The assertion that recklessness is included on the spectrum of mens rea for war crimes involves separate substantive and procedural inquiries of equal significance. From a substantive perspective, assessing the recklessness assertion requires a detailed examination of relevant sources of international criminal law because the assertion typically relies on jurisprudence from international criminal tribunals for support. From a procedural perspective, the unsettled relationship between states and international criminal tribunals must be satisfactorily clarified because the prevailing recklessness assertion relies primarily on international criminal law for support, while states retain primary responsibility for adjudicating alleged offenses that occur during armed conflict. This Article explores both inquiries with the dual objectives of refining the customary mental element for war crimes and of bringing clarity to the role of international criminal tribunals as a source of customary international law.

Both the substantive and procedural aspects of the inquiry are of critical importance in the theory and practice of public international law. Substantively, the issue of intent often constitutes the dividing line between tragic accident and war crime. Very often, the material facts involving the outcome of an attack that results in civilian casualties are not in dispute. What remains unresolved is where to draw the line between war crime and mistake. If recklessness is indeed included on the spectrum of mens rea for war crimes, many accidents can be classified among the most serious violations of international law-and

1. Letter from Sarah Margon, Washington Dir., Human Rights Watch, to Ashton Carter, Sec'y, U.S. Dep't. Def. 2 (Dec. 17, 2015), Re: Attack on MSF Hospital in Kunduz, http://www.hrw.org/ sites/default/files/supporting_resources/hrw_letter_to_sec_def_carter_on_msf_strike.pdf.

2. Medecins Sans Frontieres, Kunduz Hospital Attack: MSF Factsheet (Oct. 7, 2015), https://www. doctorswithoutborders.org/what-we-do/news-stories/news/kunduz-hospital-attack-msf-factsheet. 
potentially subject the alleged perpetrators to prosecution domestically by any capable state. If recklessness is not included on the spectrum, most accidents will not qualify as war crimes. Procedurally, the ostensive characterization of the jurisprudence from international criminal tribunals as a primary source of international law-which is required to support the prevailing recklessness assertion-constitutes a substantial expansion of the collection of primary sources of customary international law. If state practice and opinions from international criminal tribunals are in conflict and both possess authority as primary sources, the precise content of international law is indeterminate.

One central basis for the persistent ambiguity concerning both inquiries is a pervasive lack of precision in existing literature and practice involving the topics. The broad diversity of conduct that can qualify for characterization as a war crime is typically considered in unitary fashion when describing a mens rea standard that purportedly applies uniformly across the spectrum of relevant conduct. Similarly, existing discourse involving the function of international criminal tribunals as a source of customary international law generally fails to distinguish between different components of international criminal law and therefore lacks the precision needed to adequately define that role. Another factor that contributes to the persistent ambiguity inherent in both inquiries is the fragmented nature of scholarship and practice involving both topics. What is needed is a holistic approach that considers relevant factors with adequate precision and that consolidates pertinent considerations from across disparate sources of practice and scholarship. The present examination seeks to offer the degree of precision and integration needed to satisfactorily inform both unsettled issues.

The inquiry begins by establishing in detail the contours of the prevailing assertion that recklessness is included on the spectrum of mens rea that is generally applicable for war crimes as a matter of customary international law. This description provides a framework for the examination that follows. The inquiry draws necessary structure from the widely-cited recklessness assertion in the sweeping Customary International Humanitarian Law (CIHL) study published by the International Committee of the Red Cross (ICRC). The relevant provision of the CIHL study asserts, "[i]nternational case-law has indicated that war crimes are violations that are committed wilfully, i.e., either intentionally (dolus directus) or recklessly (dolus eventualis)."

3. Jean-Marie Henckaerts \& Louise Doswald-Beck, Customary international Humanitarian Law, Volume 1: Rules 574, Rule 156 (Cambridge University Press 2005), http:// www.icrc.org/en/doc/assets/files/other/customary-international-humanitarian-law-i-icrc-eng.pdf [hereinafter CIHL study]. 
This purported rule of customary international law evokes two distinct lines of inquiry that require critical assessment. The substantive aspect of the assertion involves investigating whether "international case-law" truly has established, with sufficient certainty to support inclusion as a "rule" of customary international law, that war crimes can be committed either intentionally or recklessly. The procedural aspect of the assertion involves the degree to which, if at all, "international caselaw" can be relied upon as a primary source when describing a purported rule of customary international law. The analysis performed in this Article is structured to assess each aspect, the substantive and procedural, in turn.

In Part One, the substantive analysis begins with the single example of "international case-law" cited by Rule 156 in support of the recklessness assertion, an opinion from the Delalic case of the International Criminal Tribunal for the Former Yugoslavia (ICTY). After determining that Delalic and two other lines of cases involving recklessness as a mental state for war crimes do not support the broad assertion from Rule 156, a fourth line of cases that starts with the ICTY Galic case is assessed. After demonstrating that the Galic recklessness line of cases is irreparably flawed, the statute and relevant jurisprudence from the International Criminal Court, as a central example of "international case-law" apart from the ICTY, are examined. The analysis at the conclusion of Part One determines that "international case-law" does not support the assertion that recklessness is included on the spectrum of mens rea for war crimes without significant limitations and qualifications.

Part Two then turns to consider the procedural aspect of the recklessness assertion. This portion of the analysis engages with the widelycontested role of international tribunals in establishing customary international law. Since the initial development of contemporary international criminal law in the aftermath of World War II, the precise relationship between states and international criminal tribunals-and the corresponding role of international tribunals as a source of customary law-continues as a matter that is widely debated. After considering and rejecting the prevailing approach utilized to describe the relationship between states and international tribunals, the "principal-agent" model, Part Two develops a new approach to define the relationship. This new approach, the "designate and extend" model, is then applied to the recklessness assertion to demonstrate that the assertion is deficient from a procedural perspective as well. Before engaging in a comprehensive analysis of the assertion that recklessness is a sufficient mental state to support a war crimes prosecution as a matter of 
customary international law, it is helpful to first bring focus to the various applications of the recklessness assertion.

\section{The Recklessness Assertion}

Broadly speaking, the recklessness assertion typically takes one of two forms. One general form of the assertion is a reference directly to Rule 156 of the ICRC CIHL study, either as the sole source of authority in support of the assertion or, at least, as a leading source. This seems to have emerged as the preferred method for the organization Human Rights Watch, ${ }^{4}$ including for the letter involving the Kunduz attack submitted to Secretary Carter, ${ }^{5}$ and it is a common approach in scholarship involving the topic as well. ${ }^{6}$ The other general form of the recklessness assertion is based on citations of international criminal tribunal opinions, particularly ICTY opinions. ${ }^{7}$ As the analysis in Part One describes,

4. See, e.g., Human Rights Watch, Targeting SaAda: Unlawful Coalition Airstrikes on SAADA CiTY IN YEMEN, 43 n.79 (June 30, 2015), www.hrw.org/report/2015/06/30/targetingsaada/unlawful-coalition-airstrikes-saada-city-yemen (asserting that "[c]riminal intent [for war crimes] has been defined as violations committed intentionally or recklessly" and citing to the ICRC CIHL study while noting the reference of the study to the ICTY Delalic case); HUMAN RIGHTS Watch, Hiding Behind the CoAlition: Failure to Credibly Investigate And Provide Redress FOR UNLAWFul ATtACKS IN YEMEN, 19 n.20 (Aug. 24, 2018), www.hrw.org/report/2018/08/24/ hiding-behind-coalition/failure-credibly-investigate-and-provide-redress-unlawful (asserting that serious violations of the law of armed conflict, when "committed by an individual with criminal intent-that is, intentionally or recklessly," are war crimes, and citing only to Rule 156 of the ICRC CIHL study); Human Rights Watch, "They've Shot MaNy Like This": Abusive Night Raids BY CIA-BACKED AFGHAN STRIKe FORCES, 46 n.155 (Oct. 31, 2019), www.hrw.org/sites/default/files/ report_pdf/afghanistan1019_web.pdf (asserting that "[s]erious violations of international humanitarian law committed with criminal intent-that is, deliberately or recklesslyare war crimes" and citing only to Rule 156 of the ICRC CIHL study).

5. See Letter from Sarah Margon, supra note 1.

6. See, e.g., Stuart Casey-Maslen \& Steven Haines, Hague law Interpreted: The Conduct OF HOSTILITIES UNDER THE LAW OF ARMED CONFLICT 128-29 (2018) (describing the interpretation reflected in Rule 156 of the ICRC CIHL study that the term "willfully" in the context of war crimes means "deliberate intent" or "recklessness" as a reflection of customary international law); CHILE Eboe-Osuji, 'Grave Breaches' as War Crimes: Much Ado About...'Serious Violations'? 2-3, https://www.icc-cpi.int/NR/rdonlyres/827EE9EC-5095-48C0-AB04-E38686EE9A80/283279/ GRAVEBREACHESMUCHADOABOUTSERIOUSVIOLATIONS.pdf (last visited Aug. 18, 2020) (citing Rule 156 of the ICRC CIHL study as direct support for the assertion that the term "willfully" in the context of war crimes means intentionally or recklessly).

7. See, e.g., CIHL study, supra note 3, at 568-603; Adil Ahmad Haque, What the Kunduz Report Gets Right (and Wrong), JUST SECURITY (May 10, 2016), www.justsecurity.org/30986/kunduz-reportand-wrong ("With respect to customary international law, the International Criminal Tribunal for the former Yugoslavia (ICTY) has repeatedly held that it is a war crime to 'willfully' attack civilians, where 'the notion of "wilfully' incorporates the concept of recklessness, whilst excluding mere negligence'”); Brian Finucane, Partners and Legal Pitfall, 92 INT'L L. STUD. 407, 410 (2016), 
the ICTY finding that recklessness is sufficient to support a war crimes prosecution is founded upon an ICRC assertion to that effect. ${ }^{8}$ Whether assertions from the venerable ICRC or opinions from the ICTY are directly cited for support, it seems that all, or at least most, roads in the recklessness assertion lead to the ICRC.

The analysis in this Article, then, is structured on the ICRC recklessness assertion that is reflected in Rule 156 of the CIHL study even though drawing on this formulation is not an absolute requirement in order to critically assess the general recklessness assertion. The specific text of the "rule" represents a useful summary of the recklessness assertion because the general assertion is composed of the same constituent elements-a substantive assertion regarding the conclusions of "international case-law" and a procedural reliance on jurisprudence from international criminal tribunals-as the text of Rule 156. Because of the valuable structure it provides and because the text is widely cited in support of the recklessness assertion, the present inquiry is organized around this formulation to address both aspects-substantive and procedural-of the customary "rule" described in the ICRC CIHL study. With the structure of the inquiry and the contours of the recklessness assertion thus described, the analysis turns now to consider the substantive aspect of the assertion.

\section{Part One: Substantive Assessment of the Recklessnness Assertion}

The widely-cited recklessness assertion established in the ICRC CIHL "rule" observes, "[i]nternational case-law has indicated that war crimes are violations that are committed wilfully, i.e., either intentionally (dolus directus) or recklessly (dolus eventualis)." In support of this assertion, Rule 156 cites a single ICTY opinion which was published as part

https://digital-commons.usnwc.edu/cgi/viewcontent.cgi?article=1694\&context=ils (citing to several ICTY cases in support of the observation that "certain serious LOAC violations, such as intentionally or recklessly attacking civilians or civilian objects, including specifically protected objects, constitute war crimes"); W.J. Fenrick, Senior Legal Advisor, ICTY Off. of the Prosecutor, Public Remarks, Crimes in Combat: The Relationship Between Crimes Against Humanity and War Crimes 6 (Mar. 5, 2004), www.icc-cpi.int/NR/rdonlyres/E7C759C8-C5A44AD3-8AB5-EF6ED68AC1D4/0/Fenrick.pdf (expressing the "conscious effort" of the office of the prosecutor to "argue that the law concerning unlawful attacks against civilians is, in substance, the same in both international and internal conflicts" and describing the 2003 ICTY Galić Trial Chamber opinion, which determines that recklessness is a component of the mental state of "wilful" as the "most thoughtful and elaborate decision to date by an ICTY chamber concerning unlawful attack charges against civilians").

8. See Prosecutor v. Galić, Case No. IT-98-29-T, Trial Judgement, II 54 (Int'l Crim. Trib. for the Former Yugoslavia Dec. 5, 2003).

9. CIHL study, supra note 3 , at 574 , Rule 156 . 
of the Delalić case. ${ }^{10}$ The procedural matter of whether jurisprudence from international criminal tribunals can be cited as a primary source in the effort to articulate a provision of customary international law is considered infra in Part Two. First, the substantive issue of whether "international case-law" actually does indicate that war crimes can be committed either intentionally or recklessly is critically assessed.

\section{A. The Spectrum of Mens Rea}

At the outset of the substantive evaluation, a brief overview of the spectrum of mens rea is useful since Rule 156 describes "intentionally" as synonymous with "dolus directus" and "recklessness" as synonymous with "dolus eventualis." In relation to the Kunduz airstrike that prompted the letter submitted from Human Rights Watch to the Secretary of Defense, the internal U.S. military investigation concludes that the attack does not constitute a war crime because the MSF trauma center was not attacked "intentionally." ${ }^{11}$ Relying on the specific term "intentional" for an assessment of the applicable mental state is problematic due to the significant degree of ambiguity inherent in the term. As Jens David Ohlin succinctly observes in relation to criminal law generally and international criminal law specifically, " $[\mathrm{t}]$ he word ['intent'] is notoriously vague and captures situations where the defendant desires a particular outcome as well as situations where the defendant is aware of the practical certainty of the outcome but is indifferent to the result." ${ }^{12}$

Because the concept of intent is "notoriously vague" and national jurisdictions apply different mens rea models as a result of disparate legal histories and traditions, consolidating a comprehensive-and comprehensible-spectrum of the mental element for crimes can be a

10. The Delalić case is commonly referred to in ICTY parlance as the "Čelebići" case, which is a reference to the Celebici prison camp where the offenses adjudicated in the case occurred. See, e.g., Press Release, ICTY, Celebici Case: The Judgment of the Trial Chamber (Nov. 16, 1998), https://www.icty.org/en/press/celebici-case-judgement-trial-chamber-zejnil-delalicacquitted-zdravko-mucic-sentenced-7-years.

11. See Memorandum from U.S. Cent. Command, Summary of the Airstrike on the MSF Trauma Center in Kunduz, Afghanistan on October 3, 2015; Investigation and Follow-on Actions, https:// www3.centcom.mil/FOLALibrary/cases/16-0061/00\%20CENTCOM\%20Summary\%20Memo.pdf. (last visited Aug. 18, 2020). The Central Command memorandum asserts, "The label "war crimes' is typically reserved for intentional acts-intentionally targeting civilians or intentionally targeting protected objects" (emphasis in original). According to the memorandum, because the "investigation found that the tragic incident resulted from a combination of unintentional human errors and equipment failures," the airstrike would not qualify as "intentional" and, therefore, would not be characterized as a war crime.

12. Jens David Ohlin, Targeting and the Concept of Intent, 35 MICH. J. INT’L L. 79, 82 (2013). 
challenge. While observations and explanations regarding comparative application of mental elements in criminal law abound, Mohamed Elewa Badar provides a particularly useful account when making a "case for a unified approach" to the application of mens rea in international criminal law. Although neither common law nor civil law jurisdictions present monolithic applications of the concept of mens rea, ${ }^{13}$ some general observations and comparisons are useful and apposite.

As Badar describes, what would generally be referred to as "dolus directus in the first degree" in a civil law tradition corresponds closely to the "purpose" formulation established in the U.S. Model Penal Code (MPC) ${ }^{14}$ Similarly, "dolus directus in the second degree" corresponds closely with the MPC formulation for "knowledge."15 These parallel mens rea concepts appear to correspond with the reference to "intentionally (dolus directus)" from the ICRC CIHL Rule 156 formulation. In a "typical" common law mens rea construct, the line between "intentional" and "reckless" would be drawn here-with "purpose" and "knowledge" above the "intent" line-while this is not generally the case for a "typical" civil law paradigm.

While various useful descriptions of the mens rea of dolus eventualis are presented in literature involving the topic, the ICTY Appeals Chamber decision in the Blaskic case offers a particularly effective and succinct description of the concept. In the effort to consolidate a workable application of dolus eventualis, the opinion surveys the national jurisdictions of France, Italy, and Germany, each of which adopts a civil law tradition. ${ }^{16}$ The Blaskic formulation notes that, as the German Federal Supreme Court has concluded, "in the case of extremely dangerous, violent acts, it is obvious that the perpetrator takes into account the possibility of the victim's death and, since he continues to carry out the act, accepts such a result."

13. E.g., Roger S. Clark, The Mental Element in Intermational Criminal Law: The Rome Statute of the International Criminal Court and the Elements of Offences, 12 CrIM. L. FORUM 291, 294 (2001) ("The civil law is not a monolith; the common law is not a monolith").

14. Mohamed Elewa Badar, The Concept of Mens Rea in International Criminal LaW, The CASE FOR A UNIFIED APPROACH 423 (2013).

15. Id. For a useful graphical consolidation of these and other mens rea concepts, see also Sarah Finnin, Mental Elements under Article 30 of the Rome Statute of the International Criminal Court: A Comparative Analysis, 61 INT'L \& CoMP. L. Q. 325, 329 (Apr. 2012).

16. See generally Mohamed Elewa Badar, Dolus Eventualis and the Rome Statute Without It?, 12 New Crim. L. Rev. 433, 452-59 (2009) (comparing implementation of the concept of dolus eventualis in selected civil law jurisdictions, including Egypt, France, Italy, South Africa, and Germany).

17. Prosecutor v. Blaškić, Case No. IT-95-14-A, Appeals Judgment, II 39 (Int'l Crim. Trib. for the Former Yugoslavia July 29, 2004). 
this "volitional element" of being aware of the risk, accepting the result, and acting even with the awareness of the risk that "denotes the borderline between dolus eventualis and advertent or conscious negligence."18

When applied in a "typical" common law jurisdiction, dolus eventualis is often described as being akin to recklessness, although dolus eventualis is, at least in theory, more restricted in a way that the perpetrator need not only be aware of the risk but must also accept the possibility that the criminal consequence occurs. ${ }^{19}$ One useful way of describing the volitional aspect of dolus eventualis in context is that the "offender must 'reconcile himself' . . . to the prohibited result" of his or her actions. ${ }^{20}$ Although this volitional element, at least theoretically, sets dolus eventualis apart from the common law recklessness counterpart, as Sarah Finnin observes, "[c]ommentators disagree . . . on whether recklessness (in common law) and dolus eventualis (in civil law) are really different, and in what way." 21 As Jens Ohlin similarly points out, "[a] debate rages among international lawyers over whether dolus eventualis is exactly the same as recklessness, or whether it represents a mental state that is slightly more culpable than common law recklessness because it requires an identification with the evil result that represents a malignant heart."22

While there seems to be no reason to doubt that dolus eventualis and recklessness are conceptually distinguishable, in practical application both formulations "would usually cover the same factual constellations." 23 This is because a perpetrator who is aware of a risk, which is conceptually sufficient in the recklessness context, likely also factually reconciles herself or himself to the possibility that the criminal consequence will occur before the action is performed, which is the "additional" requirement to be demonstrated in the dolus eventualis context. In any event, it is the ostensibly volitional requirement of "reconciling oneself" with the possibility of the criminal outcome that, at least conceptually, places dolus eventualis above the line for "intent" in a "typical" civil law jurisdiction, ${ }^{24}$ while the absence of this volitional aspect places

18. $I d$.

19. Elies van Sliedregt, Indivudual Criminal Responsibility in InTernational LaW 45 (2012).

20. Mohamed Elewa Badar, Mens rea-Mistake of Law $\mathcal{G}$ Mistake of Fact in German Criminal Law: A Survey for International Criminal Tribunals, 5 INT'L CRIM. L. REV. 203, 228 (2005).

21. Finnin, supra note 15 , at 330.

22. Ohlin, supra note 12 , at 89 .

23. Finnin, supra note 15, at 336 (citation omitted).

24. While most continental civil law jurisdictions include dolus eventualis on the spectrum of intent, the French model is unique in that, like the common law category, dolus eventualis is 
recklessness below the conceptual line for "intent" in the common law tradition.

Consolidating the various models of intent described above, then, it is uncontroversial to include common law concepts of "purpose" and "knowledge" on the spectrum of intent that is sufficient to sustain a war crimes prosecution. These concepts roughly correlate with the civil law application of dolus directus in the first degree ("purpose") and in the second degree ("knowledge"). These mental element standards are included on the spectrum of intent that is required to support a criminal prosecution pursuant to the Rome Statute of the International Criminal Court ${ }^{25}$ and, for example, in jurisprudence from the ICTY. ${ }^{26}$

While there is some conceptual distinction between recklessness and dolus eventualis, these terms are consolidated for present purposes since they would usually cover the same factual constellations. Likewise, the mens rea formulation asserted by Rule 156 of the ICRC CIHL study uses the terms "recklessly" and "dolus eventualis" interchangeably. ${ }^{27}$ It is the inclusion of the combined concepts of recklessness and dolus eventualis on the spectrum of mens rea that is, purportedly, sufficient to support a war crimes prosecution as a matter of customary international law wherein the controversy is to be found. With the pertinent spectrum of mens rea thus briefly examined, the present inquiry regarding the substantive aspect-whether "international case-law" actually does support the recklessness assertion-continues.

applied as a transitional concept between intent and negligence. See BADAR, supra note 14 , at 418 (characterizing the French model as "the only exception to a rule" that "continental law jurisdictions do not operate with" an intermediary between intent and negligence). Even though the French model stands alone in the continental civil law category by excluding dolus eventualis from the spectrum of intent, the conceptual presence of the volitional element of the acceptance of a risk is not a feature of the common law concept of recklessness.

25. See Rome Statute of the International Criminal Court art. 30, July 17, 1998, 2187 U.N.T.S. 90 (entered into force July 1, 2002), rev. 2010 [hereinafter Rome Statute].

26. See, e.g., Prosecutor v. Galić, Case No. IT-98-29-T, Trial Judgement, II 54 (Int'l Crim. Trib. for the Former Yugoslavia Dec. 5, 2003). The Galic trial chamber decision cites to the ICRC Commentary to Additional Protocol I, infra note 54, to conclude that an accused "must have acted consciously and with intent, i.e., with his mind on the act and its consequences, and willing" the consequences. This mens rea formulation adopted from the ICRC incorporates, without controversy, the common law "purpose" and "knowledge" counterparts while, contentiously, incorporating dolus eventualis into the spectrum of "intent."

27. Recall that the relevant text of Rule 156 asserts that "[i]nternational case-law has indicated that war crimes are violations that are committed wilfully, i.e., either intentionally (dolus directus) or recklessly (dolus eventualis)." CIHL study, supra note 3 , at 574 . 


\section{B. ICTY Jurisprudence: Detainee Abuse and the Cited Delalić Decision}

The substantive analysis in Part One begins by examining the single source cited by the ICRC recklessness "rule": the trial chamber decision in the ICTY Delalić case. It is worth noting at the outset of the substantive inquiry that referring to a single case in international criminal jurisprudence is an insufficient predicate upon which to base an assertion that any particular practice constitutes a rule of customary international law. However, the procedural examination, specifically assessing the role of "international case-law" as a source of customary international law, is performed in Part Two. For now, the Delalic opinion, along with similar examples of "international case-law" that could ostensibly support the recklessness assertion but are not cited by the ICRC CIHL study, are considered in order to assess the substantive aspect of the recklessness assertion.

The ICTY Delalić case involves a group of four defendants, Zejnil Delalić being the first name listed, that were accused of various serious incidents of detainee abuse, including murder, at the Čelebići prison camp in central Bosnia and Herzegovina during the armed conflict in the former Yugoslavia. ${ }^{28}$ The portion of the Delalic trial chamber decision cited by the ICRC CIHL study in support of the recklessness assertion involves the war crime of "wilful killing" or "murder," which the chamber considers to be synonymous, ${ }^{29}$ of a detainee during armed conflict. While exploring the legal standard to be applied, the chamber observes that the war crime of murder involves an actus reus and mens rea. For the actus reus, the chamber equates murder with "homicide of all natures" and concludes "this actus reus is clearly the death of the victim as a result of the actions of the accused." 30 The opinion then turns to explore the mens rea that is required to support the war crime of "wilful killing" or "murder."

The mens rea analysis begins by surveying various methods by which several national jurisdictions apply the mens rea requirement to the crime of murder. ${ }^{31}$ After the brief survey, the trial chamber concludes that there can be "no doubt that the necessary intent, meaning mens rea, required to establish the crimes of wilful killing and murder . . . is present where there is demonstrated an intention on the part of the

28. See generally Prosecutor v. Delalić, Case No. IT-96-21-T, Trial Judgement, II 3 (Int'l Crim. Trib. for the Former Yugoslavia Nov. 16, 1998).

29. See id. If 433 (concluding, after a brief analysis, that "no difference of consequence flows from the use of "wilful killing' in place of 'murder'").

30. Id. II 424.

31. See id. पI $434-437$. 
accused to kill, or inflict serious injury in reckless disregard of human life."32 This is the specific conclusion cited by the ICRC CIHL recklessness assertion in support of the general observation that "war crimes are violations that are committed wilfully, i.e., either intentionally (dolus directus) or recklessly (dolus eventualis)."33

It is true that this formulation from the Delalic trial chamber opinion supports the conclusion that recklessness is part of the spectrum of mens rea required to sustain a prosecution for the murder of a detainee. However, extrapolating from this limited application of recklessness a broad statement regarding all war crimes, including directing attacks against civilian persons or objects, represents a category error that renders the general conclusion erroneous. The conceptual and practical distinctions between using force in a detention context and in a targeting context is examined in the next section when assessing the ICTY Galic line of cases. For now, it is worth noting that the mens rea standard for the war crime of murder in the Delalic trial chamber decision involves a very specific circumstance of willful killing of a detainee.

More precisely, the factual record presented to the tribunal often indicated that the abuse inflicted by the accused on various occasions did not cause the direct and immediate death of the victim detainees. Rather, in many cases the victims died from injuries sustained by severe beatings several hours or days after the abuse ended and the accused was no longer present with the victim. Under these circumstances, the trial chamber determined that inflicting serious bodily injury "in reckless disregard of human life" is tantamount to deliberately murdering the victim. $^{34}$

It is in this context-when a detainee is killed and "there is demonstrated an intention on the part of the accused to kill, or inflict serious injury in reckless disregard of human life"-that the Delalic trial chamber "is in no doubt that the necessary intent, meaning mens rea, required to establish the crimes of wilful killing and murder, as recognised in the Geneva Conventions, is present." ${ }^{35}$ Further, it is "in this light that the evidence relating to each of the alleged acts of killing is assessed and the appropriate legal conclusion reached"36 by the Delalic trial chamber. While Rule 156 of the ICRC CIHL recklessness assertion cites (exclusively) to this ICTY opinion in support of the assertion that

\footnotetext{
32. Id. II 439.

33. CIHL study, supra note 3, at 574 .

34. See, e.g., Delalić, Trial Judgment, पा पा 823, 845, 855, 877, $894 \& 908$ (emphasis added).

35. Id. II 439 (emphasis added).

36. Id. (emphasis added).
} 
"international case-law has indicated" that war crimes can be committed either "intentionally (dolus directus) or recklessly (dolus eventualis)," the sole reference cited supports only a much more limited recklessness assertion.

Based exclusively on the cited Delalić case, a more tenable observation is that an ICTY opinion has indicated that the war crimes of willful killing and murder can be committed in the detainee abuse context in two specific scenarios: first, when the accused deliberately kills the victim detainee; and second, when the accused inflicts serious injury in reckless disregard of human life and the victim detainee later dies from the injuries inflicted by the accused. Extrapolating from this limited conclusion that war crimes generally can be committed "either intentionally or recklessly" is not a faithful application of the finding-and the reasoning provided to support the finding-of the cited Delalic opinion.

This ICTY Delalic opinion is the only example of "international case-law" cited by the ICRC CIHL study in support of the recklessness assertion. However, there are other specific lines of ICTY opinions that could potentially support the assertion that the jurisprudence of international criminal tribunals has indicated that recklessness is a sufficient mens rea to support a war crimes prosecution. Two of these lines of cases, one involving participation in a joint criminal enterprise and the other involving command responsibility, represent specific and limited circumstances, as does the Delalić line. These two lines of cases are examined briefly before considering the Galic line, which could potentially support a more general recklessness assertion.

\section{ICTY Jurisprudence:Joint Criminal Enterprise and Command Responsibility}

In relation to the context of participation in a joint criminal enterprise, an ICTY appeals chamber decision in the Tadic case is the first to articulate a standard that involves the possibility of recklessness as a sufficient mens rea. ${ }^{37}$ The opinion considers three discreet categories of co-perpetration for which the tribunal will evaluate the individual criminal responsibility of the alleged co-perpetrators. The first two categories involve a common design of the co-perpetrators, and the third category involves a joint criminal enterprise but not necessarily a

37. Prosecutor v. Tadić, Case No. IT-94-1-A, Appeals Judgment, If 220 (Int'l Crim. Trib. for the Former Yugoslavia July 15, 1999). 
common design. It is only in this third category of joint criminal enterprise cases that the appeals chamber determines that recklessnessspecifically the related mens rea concept of dolus eventualis-is sufficient for a finding of criminal liability for a member of the enterprise.

More specifically, the opinion determines that for the first two categories of accomplice liability, actual personal knowledge of the specific crime committed by the group and intent to contribute to that crime are required for each co-perpetrator. ${ }^{38}$ The third category described by the appeals chamber involving a joint criminal enterprise concerns individual criminal responsibility for a specific crime the defendant coperpetrator did not necessarily intend to commit. For this category, the appeals chamber determines that, as a threshold matter, the accused must demonstrate "an intention to participate in and further the criminal activity or the criminal purpose." 39

With the threshold thus established, the opinion determines that "responsibility for a crime other than the one agreed upon in the common plan arises only if, under the circumstances of the case, (i) it was foreseeable that such a crime might be perpetrated by one or other members of the group and (ii) the accused willingly took that risk." ${ }^{" 0}$ This foreseeability component related to responsibility for a crime "other than one agreed upon" is described by the judgement as dolus eventualis, or advertent recklessness. ${ }^{41}$ While Tadic represents an early example of jurisprudence from the ICTY-it was the first contested case tried before the trial chamber and the first contested trial to reach the appellate chamber-the mens rea construct related to cases of joint criminal enterprise established in Tadić was later adopted and applied throughout decisions of the tribunal, including the landmark Stakic case ${ }^{42}$ and the Prlic case, ${ }^{43}$ which was the last major decision published by the appeals chamber for the tribunal.

Transitioning now to consider the context of command responsibility, the mens rea of recklessness as characterized by the tribunal involves issuing orders to subordinates who go on to commit a crime.

38. See id. If 228 (requiring shared intent to perpetrate a specific crime for the first category and describing the second category as "really a variant of the first" and requiring "personal knowledge of the system of ill-treatment" for the second category).

39. Id. II 228 (emphasis in original).

40. Id. II 228 (emphasis added).

41. See id. đ 220.

42. See Prosecutor v. Stakić, Case No. IT-97-24-A, Appeals Judgement, II 65 (Int'l Crim. Trib. for the Former Yugoslavia Mar. 22, 2006).

43. See Prosecutor v. Prlić, Case No. IT-04-74-A, Appeals Judgement, II 587 (Int'l Crim. Trib. for the Former Yugoslavia Nov. 29, 2017). 
In this context, the Blaškic appeals chamber determined that a "person who orders an act or omission with the awareness of the substantial likelihood that a crime will be committed in the execution of that order, has the requisite mens rea for establishing liability." 44 The opinion concludes that, "an awareness of a higher likelihood of risk and a volitional element must be incorporated in the legal standard"45 for command responsibility and that "[o]rdering with such awareness has to be regarded as accepting that crime." ${ }^{46}$ In the context of command responsibility, then, the tribunal adopts a standard of dolus eventualis as an adequate mens rea to support a war crime prosecution. The tribunal applies this standard to the relevant factual record, whereby the appellant, among other crimes, knew his subordinates were using prisoners of war as human shields and failed to take action to stop the subordinates from doing so.

Like inflicting serious bodily injury in "reckless" disregard for human life from the Delalic line of ICTY cases, the mens rea of recklessness in the contexts of joint criminal liability and command responsibility established in Tadić and Blaškić, respectively, reflects only limited applicability. In the general context of "recklessness" in a targeting scenario, liability for a joint "criminal" enterprise would only attach, according to the Tadic test, when an accused agreed to commit some other crime, it was foreseeable that other members of the group would, say, make civilians the object of attack, and the accused willingly took the risk of engaging in the attack anyway. Pursuant to the Blašic command responsibility test, a commander would need to order an attack "with the awareness of the substantial likelihood" that subordinates would, say, make civilians the object of attack "in the execution of that order" in order for criminal liability to attach in a targeting context. While each of these lines of cases establishes a limited basis on which to conclude that "international case-law has indicated" that war crimes can be committed either "intentionally" or "recklessly," there is one line of ICTY cases that could ostensibly support a more general assertion. The present inquiry turns now to the general recklessness standard reflected in an opinion from the ICTY Galic case.

44. Prosecutor v. Blaškić, Case No. IT-95-14-A, Appeals Judgment, II 42 (Int'l Crim. Trib. for the Former Yugoslavia July 29, 2004).

45. Id. II 41 .

46. Id. II 42. 


\section{ICTY Jurisprudence: Targeting in Armed Conflict}

Although it is not cited by the ICRC CIHL study, the line of cases beginning with the ICTY trial chamber opinion in the Galic case directly involves the matter of whether an attack on civilians can be considered a war crime if it is found to have been conducted recklessly. The trial chamber in Galic determined that a "perpetrator who recklessly attacks civilians acts "wilfully" 47 and that, in accordance with Article 85 of Additional Protocol I to the 1949 Geneva Conventions (AP I), "wilfully 'making the civilian population or individual civilians the object of attack" "qualifies as a grave breach. ${ }^{49}$ This conclusion, that an attack that causes death or serious injury to civilians qualifies as willful if it is determined to be reckless, was upheld without significant discussion by the appeals chamber ${ }^{50}$ and adopted as a matter of settled law in subsequent ICTY opinions. ${ }^{51}$ Careful scrutiny of the Galic recklessness standard, however, reveals that the mens rea formulation rests on a questionable legal analysis and that the relevant judicial opinions do not actually apply the dubious recklessness standard in practice.

\section{Galić and the Foundation for Recklessness in Targeting Civilians}

In setting the foundation for determining that recklessness is a sufficient mens rea in a targeting context, the Galic trial chamber opinion cites directly to AP I to make the uncontroversial finding that "wilfully 'making the civilian population or individual civilians the object of attack'" qualifies as a grave breach. ${ }^{52}$ This finding supports the conclusion that such conduct falls within the subject matter jurisdiction of the tribunal. While the grave breach observation is uncontentious based on

47. Prosecutor v. Galić, Case No. IT-98-29-T, Trial Judgement, II 54 (Int'l Crim. Trib. for the Former Yugoslavia Dec. 5, 2003).

48. See Protocol Additional to the Geneva Conventions of 12 August 1949, and Relating to the Protection of Victims of International Armed Conflicts (Protocol I), art. 85, June 8, 1977, 1125 U.N.T.S. 3 [hereinafter AP I].

49. Galić, Trial Judgment, II 54 (citing AP I, art. 85) (emphasis in original).

50. See Prosecutor v. Galić, Case No. IT-98-29-A, Appeals Judgment, II 140 (Int’l Crim. Trib. for the Former Yugoslavia Nov. 30, 2006) (concluding that the "Trial Chamber's reasoning in this regard is correct").

51. See, e.g., Prosecutor v. Strugar, Case No. IT-01-42-T, Trial Judgment, II 240 (Int'l Crim. Trib. for the Former Yugoslavia Jan. 31, 2005); Prosecutor v. Strugar, Case No. IT-01-42-A, Appeals Judgment, II 270 (Int'l Crim. Trib. for the Former Yugoslavia July 17, 2008); Prosecutor v. Perišić, Case No. IT-04-81-T, Trial Judgment, II 201 (Int'l Crim. Trib. for the Former Yugoslavia Sept. 6, 2011).

52. Galić, Trial Judgment, If 54 (citing AP I, art. 85(3) (a)) (emphasis in original). 
a textual reading of $\mathrm{AP} \mathrm{I}$, it is a miscalculated attempt to interpret and apply a definition for the mens rea of "willful" based on this textual reading that introduces the error upon which the Galic recklessness standard and the subsequent jurisprudence that applies the Galićstandard are founded.

In search of an interpretation for the crucial mens rea concept of willfulness, the trial chamber considers a single source, the ICRC commentary on AP I, and simply "accepts this explanation" from the ICRC with no discussion, critical assessment, or consideration of other sources. The ICRC commentary upon which the trial chamber exclusively relies asserts that the mens rea of willful "encompasses the concepts of 'wrongful intent' or 'recklessness', viz., the attitude of an agent who, without being certain of a particular result, accepts the possibility of it happening." The Commentary concludes that, "on the other hand, ordinary negligence or lack of foresight is not covered, i.e., when a man acts without having his mind on the act or its consequences. $" 55$ Had the Galic trial chamber engaged in a careful and critical appraisal of this characterization, a number of fundamental defects in the reasoning provided by the ICRC in support of the recklessness assertion would have counseled against relying on this source, to the exclusion of all others, as a correct formulation of the term "willful."

The initial flaw that is apparent, with even minimal investigation, in the ICRC AP I Commentary mens rea assertion is the sources upon which the assertion relies for support. The first source cited in support of the mens rea claim simply discusses differences in national interpretations, as the Commentary itself acknowledges by observing that the cited sources examine "various [mens rea] concepts which are not all defined identically by national law." 56 The second and final ${ }^{57}$ source cited by the ICRC Commentary in support of the assertion that recklessness is included in the spectrum of mens rea for willfulness is the ICRC Commentary itself. Specifically, the relevant citation ${ }^{58}$ directs the

53. Id.

54. Int'l Comm. of the Red Cross, Commentary on the Additional Protocols of 8 June 1977 to the Geneva Conventions of 12 August 1949, II 3474 (Yves Sandoz et al. eds., 1987) [hereinafter ICRC Commentary].

55. Id.

56. Id. at 994 n.14 (emphasis added).

57. The Commentary footnote being examined goes on to cite another provision of the Commentary involving the discussion of "failure to act and on negligence," which is beyond the scope of the current discussion involving recklessness and mens rea.

58. ICRC Commentary, supra note 54, at 994 n.14. 
reader to the discussion within the Commentary involving willfulness as a mens rea in relation to Article 11 of AP I.

Besides the notable flaw of exclusively citing internally to the ICRC Commentary to support an assertion made within the ICRC Commentary, careful examination of the mens rea discussion related to Article 11 of AP I that is invoked by the discussion regarding Article 85 reveals several deficiencies that render the ICRC interpretation erroneous. Perhaps the most obvious fault is an ambiguity involving translation that is invited by the method employed by the Commentary to consolidate two French terms into one English expression. Specifically, the Commentary notes that the official French language version of AP I utilizes the term "intentionnel" in Article 85 and "volontaire" in Article 11, while the official English language version of the treaty employs the term "wilful" in both instances. ${ }^{59}$ On this basis alone, the Commentary determines "it is clear that there is no difference of meaning" between the French and English interpretations of intent. ${ }^{60}$

This cross-language ambiguity that is invited by the ICRC methodology is used to support the conclusion that, while mere negligence is excluded, "the concept of recklessness that may come into play-the [accused] accepts the risk in full knowledge of what he is doing-must also be taken to be part and parcel of the concept of wilfulness." ${ }^{61}$ While the conclusion that recklessness is "part and parcel" of willfulness is clear, the source of the supposed definition of recklessness-the accused "accepts the risk in full knowledge of what he is doing"-is not explained at all. Furthermore, the supposition that "it is clear that there is no difference in meaning" between the concepts of intent simply because the French text of the treaty utilizes two different terms while the English version uses only one term is not at all "clear." At the conclusion of an analysis that represents the linguistic equivalent of a carnival shell game, the ICRC Commentary concludes-with no support other than a translation ambiguity and an unidentified source for a definition of recklessness - that recklessness is "part and parcel" of the mens rea concept of willfulness.

This contention, of course, does not withstand even negligible critical scrutiny. The existence of disparate broad categories of mens rea, and specific nuances apparent within the various broad traditions, among national understandings of mens rea in domestic criminal law reveals the true diversity of this core concept. To conclude that because

\footnotetext{
59. Id. at 159 n.15.

60. Id

61. Id. II 493 (emphasis in original).
} 
the French text of a treaty utilizes two words to describe a specific mental state while the English version uses one word indicates that there is "no difference in meaning" between the French and English understanding of intent belies the richness and diversity inherent in different understandings of intent. The assertion in the ICRC Commentary to AP I that recklessness is "part and parcel" of willfulness on this basis alone is not supportable by any measure of prudent analysis. That the Galic decision simply "accepts this explanation" from the ICRC Commentary and that subsequent ICTY decisions cite the Galic decision as support with no further independent analysis impugns the entire line of reasoning involving recklessness and "willfulness" that begins with the trial chamber decision in Galic. As such, further scrutiny is warranted, rather than, as does the Galic decision, merely accepting the explanation reflected in the ICRC Commentary to AP I without critical analysis.

As an initial matter, the practical difference between a scenario, such as in Delalic, where a person under the control of a belligerent is wounded or killed and a scenario, such as in Galić, where civilians are wounded or killed in a targeting context, must be considered. This distinction is of central importance because the provision of the ICRC Commentary to AP I that is relied upon by the Galic trial chamber addresses Article 85 of AP I while referring internally to the Commentary observations related to Article 11 of AP I. Article 11 of AP I addresses the protection of persons "who are in the power of the adverse Party" or otherwise detained, while Article 85 addresses the same scenario and adds offenses that constitute violation of the targeting distinction and proportionality rules to the list of "grave breaches" established by the treaty. If there is a legal and conceptual distinction between attacking in a detention scenario and doing so in a targeting scenario, as the analysis below affirmatively demonstrates, then this distinction must be adequately accounted for when formulating the legal test for each. The failure of the ICRC AP I Commentary to distinguish between the different contexts when comparing the mens rea required for each renders the direct equivalence of Article 11 and Article 85 erroneous, along with the cursory "analysis" of the Galic trial chamber that "accepts this explanation" with no critical evaluation.

In relation to a detention scenario, such as that considered in Delalic and described in Article 11 of AP I, the presumption is that violent force does not need to be used against the detainee because the detainee has been rendered hors de combat and therefore no longer qualifies as a military objective. As such, there is no cognizable military necessity to use violent force against the detainee unless an agent of the 
detaining power must do so for some justifiable reason such as, for example, in self-defense or to prevent an escape. Furthermore, there is no question on the part of an agent of the detaining power that the detainee is hors de combat because the agent has already perfected custody and control over the detainee.

In this scenario, which again is the single, specific scenario reflected in Article 11 of AP I, the detainee is completely reliant upon the detaining power for his or her care and wellbeing. Killing the detainee under these circumstances, without an adequate affirmative defense, would qualify for the grave breach of willful killing established in all four 1949 Geneva Conventions. Doing so, either with the intent to kill or with the intent to inflict serious injury in reckless disregard of human life, qualifies for the war crimes of willful killing or murder pursuant to the Delalic formulation.

The factual scenario involved in the Galic trial chamber decision is fundamentally different-conceptually and as a matter of international law-than the detainee abuse setting involved in the Delalic test. Although there is presumably no justification to use force in the Delalic detainee context absent an exception such as self-defense, the opposite presumption prevails in the Galićtargeting context. While articulations of the general military necessity principle abound in the literature involving armed conflict, one particularly concise and pertinent formulation of military necessity observes, "[m] ilitary necessity permits a belligerent, subject to the laws of war, to apply any amount and kind of force to compel the complete submission of the enemy with the least possible expenditure of time, life, and money."62 Practical application of the principle of military necessity is reflected in the AP I provision involving military objectives, which establishes:

Attacks shall be limited strictly to military objectives. In so far as objects are concerned, military objectives are limited to those objects which by their nature, location, purpose or use make an effective contribution to military action and whose total or partial destruction, capture or neutralization, in the circumstances ruling at the time, offers a definite military advantage. ${ }^{63}$

The conceptual difference in the types of necessity involved in using force in a targeting context and doing so in a detention context is

62. United States v. List, XI Trials of War Criminals Before the Nuremberg Military Tribunals 757, 1253 (1950) [hereinafter "Hostage Case"].

63. AP I, supra note 48 , art. 52(2). 
succinctly suggested in the description by Jens Ohlin and Larry May of necessity as a "cluster concept." According to this conceptual construct, necessity in international law operates, depending on the factual context, as a license, exception, or constraint. A combatant involved in a targeting scenario in an armed conflict context is using force as a license: that is, the combatant is engaged in an "action [that] is part of a role, and to satisfy this role it is necessary for" $" 65$ the combatant to employ force. The targeting context is conceptually and factually different from the "necessity" to use force against a detainee. In the detention context, necessity for an individual soldier to use force against a detainee could be conceptualized as an "exception to an otherwise binding obligation in the sense that if it is necessary for one to act . . one is entitled to use means . . . that would normally not be permissible."66 Because of the degree of power and control exercised by the detaining power over detainees, necessity as it relates to the detaining power (rather than to an individual soldier of the detaining power) is better characterized as a constraint "that blocks a form of activity [attacking detainees] due to the lack of necessity" that would permit that activity. ${ }^{67}$

The conceptual incongruence involving the necessity of employing force in the targeting and detention contexts is manifestly apparent in the two different "streams" of the law of armed conflict. In the context of detention in armed conflict, the presumption that violent force is prohibited has deep historical roots ${ }^{68}$ and continues to animate the socalled "Geneva stream" of the law of armed conflict today. ${ }^{69}$ In the targeting context, which is more closely related to the so-called "Hague

64. See JENS DaVid OHLin \& LARRY MAY, NECESSITY in INTERNATIONAL LAW 2-6 (2016).

65. Id. at 3 .

66. Id.

67. Id.

68. See, e.g., William Wintrhop, Military LAW AND Precedents 788 (2d ed. 1920) ("Modern sentiment and usage have induced in the practice of war few changes so marked as that which affects the status of prisoners of war. The time has long passed when 'no quarter' was the rule on the battlefield, or when a prisoner could be put to death by virtue simply of his capture."); 2 FRANCis LiEber, THE Miscellaneous WRITINGS OF FRANCIS LIEBER 258 (1881) ("A prisoner of war is subject to no punishment for being a public enemy, nor is any revenge wreaked upon him by the intentional infliction of any suffering, or disgrace, by cruel imprisonment, want of food, by mutilation, death, or any other barbarity.").

69. See generally Geneva Convention Relative to the Treatment of Prisoner of War art. 3, Aug. 12, 1949, 6 U.S.T. 3316, 75 U.N.T.S. 135 [hereinafter GC III]; AP I, supra note 48, art. 75. Specific sections of AP I addressing the Geneva stream, along with the corresponding individual treaty of the 1949 Geneva Conventions, are: Part II of AP I corresponds to the nature of protections established in Geneva Conventions I and II of 1949; Part III, Section II of AP I corresponds to the 
stream" of the law of armed conflict, the often uncertain nature of the enemy disposition ${ }^{70}$ combined with the requirement to "apply any amount and kind of force to compel the complete submission of the enemy with the least possible expenditure of time, life, and money"71 presents a glaring conceptual and practical contrast to engaging in an attack in the detention context. This contrast between the detention and targeting contexts is apparent in the string of understandings or reservations to AP I published ${ }^{72}$ by States party, such as the United Kingdom, ${ }^{73}$ Italy, ${ }^{74}$ Australia, ${ }^{75}$ New Zealand,${ }^{76}$ Austria, ${ }^{77}$ and Canada, ${ }^{78}$ in the targeting context that do not apply equally in the detention context. While it may be a common sentiment that the distinction between the so-called Geneva and Hague streams of the law of armed conflict is of declining importance ${ }^{79}$ since contemporary treaties tend to consolidate provisions involving the two streams into a single

nature of protections established in GC III; and Part IV, Section II of AP I corresponds to the nature of protections established in Geneva Convention IV of 1949.

70. See, e.g., Hostage Case at 1297 ("The course of a military operation by the enemy is loaded with uncertainties, such as the numerical strength of the enemy, the quality of his equipment, his fighting spirit, the efficiency and daring of his commanders, and the uncertainty of his intentions.").

71. Id. at 1253 .

72. For the sake of brevity and to avoid unnecessary repetition in the notes that follow, this Article provides a brief summary of two main themes relevant to the present inquiry that emerge from the specific understandings, declarations, and reservations cited in the six footnotes that follow. First, the provision of AP I requiring attacks to be directed against military objectives does not involve the issue of so-called "collateral damage." Second, law of armed conflict compliance of personnel involved in an attack will be evaluated based on the information that is reasonably available to them at the relevant time. See ICRC, Treaties, States Parties and Commentaries-by State for a useful compilation of, among other relevant documents, understandings, declarations, and reservations of states that have ratified AP I, https://ihl-databases.icrc.org/applic/ihl/ihl. nsf /States.xsp?xp_viewStates=XPages_NORMStatesParties\&xp_treatySelected=470 (last visited Aug. $18,2020)$.

73. United Kingdom of Great Britain and Northern Ireland, Declaration and Reservations for AP I, Re: Article 52 (Jul. 2, 2002).

74. See Italy, Declaration for AP I (Feb. 27, 1986).

75. See Australia, Declaration for AP I (Jun. 21, 1991).

76. See New Zealand, Declaration for AP I (Feb. 8, 1988).

77. See Austria, Reservations for AP I (Aug. 13, 1982).

78. See Canada, Reservations and Understandings for AP I (Nov. 20, 1990).

79. See, e.g., Emily Crawford \& Alison Pert, International Humanitarian Law 33 (2d ed. 2020) (asserting that the terms "Hague Law" and "Geneva Law" are "[u]seful as descriptive, but essentially non-legal terms" that "efficiently summari[ze] the dual aims of" the law of armed conflict); Mary Ellen O'Connell, Historical Development, in THE HandboOK OF INTERNATIONAL Humanitarian LAw 22 (Dieter Fleck ed., 3d ed. 2013) (asserting that the "borderline between Hague and Geneva Law has now largely been eroded and AP I contains elements of both these legal traditions"). 
document ${ }^{80}$ the conceptual and practical distinction between the two is still very much relevant and apparent. Conflating the two distinct streams in a legal analysis represents a category error that can render the analysis conceptually deficient, notwithstanding the trend in favor of textual merger as a matter of convenience.

This conceptual conflation accounts for the legal error introduced by the analysis reflected in the ICRC AP I Commentary when it asserts that recklessness is "part and parcel" of willfulness and that recklessness, therefore, qualifies in general as a grave breach. Both Article 11 and Article 85 of AP I include reference to the term "wilful" in describing conduct proscribed by the respective articles. However, Article 11 deals exclusively with protections for those "in the power" of an adversary, while Article 85 refers specifically to the protections reflected in Article 11 while adding violations that would occur in a targeting context such as "making the civilian population or individual civilians the object of attack." 1

The practical realities and different applications of the cluster concept of necessity discussed above, as reflected in the state reservations and understandings related specifically to provisions of AP I involving the targeting context, require the scenario of "making the civilian population ... the object of attack," which is reflected in Article 85, to be considered differently than a scenario in which a detainee is "in the power" of an adversary, which is reflected in Article 11. Treating the two distinct contexts as conceptual equivalents renders the assertion in the ICRC AP I Commentary that recklessness is "part and parcel" of both contexts deficient. That the conceptual conflation relies on a translation ambiguity and an unidentified legal standard makes the assertion fundamentally implausible.

When the ICTY Galić decision simply "accepts this explanation" by the ICRC AP I Commentary with no critical analysis, the trial chamber adopts the same category error committed by the Commentary to enunciate an erroneous mens rea standard. The Galic appeals chamber concludes that the "Trial Chamber's reasoning in this regard is correct" ${ }^{\prime 2}$ with no critical analysis. Likewise,

80. See, e.g., Legality of the Threat or Use of Nuclear Weapons, Advisory Opinion, 1996 I.C.J. Rep. 226, II 75 (July 8) (briefly surveying the foundations of the Hague and Geneva streams and observing that the textual convergence reflected in AP I "give[s] expression and attest[s] to the unity and complexity of" the law of armed conflict).

81. AP I, supranote 48 , art. 85 (3) (a).

82. Prosecutor v. Galić, Case No. IT-98-29-A, Appeals Judgment, II 140 (Nov. 30, 2006). 
subsequent decisions simply adopt this dubious mens rea formulation as a matter of settled law. ${ }^{83}$

Notwithstanding the adoption of a mens rea formulation with dubious foundations, careful analysis of the Galic opinion and the subsequent decisions that adopt the reasoning reveals that none of the judgements actually do apply recklessness as a sufficient mental element to support a prosecution for war crimes. The Galić opinion articulating that recklessness is sufficient does so in the context of supporting a guilty verdict for a defendant, General Stanislav Galić, who reportedly conducted a coordinated and protracted "campaign of sniper attacks" and "artillery and mortar shelling" 85 against the civilian population of Sarajevo without distinguishing between military objectives and civilian objects. Without a doubt, these indiscriminate attacks were conducted with "reckless disregard of human life," to borrow from the Delalic recklessness standard in the detainee abuse context. However, the Galić trial chamber concludes that such attacks were, "at the very least, indiscriminate as to" the target, and were, therefore, directed at the civilian population. $^{86}$

Without describing it as such, the analysis in which the trial chamber is engaged when evaluating these indiscriminate attacks is actually an effort to differentiate between the mens rea concepts of "purposeful" and "knowingly" - or, to borrow generally from civil law terminology, of dolus directus in the first and second degrees. While the trial chamber does not rule out the possibility that such attacks were conducted for the purpose of targeting civilians, the opinion recognizes that this higher level of mens rea is not necessarily required. By concluding that the attacks were "at the very least indiscriminate," 87 the trial chamber finds that the defendant knowingly made the civilian population the object of attack while not ruling out the possibility that such attacks were for the purpose of attacking civilians. Although the opinion uses the word "reckless" to describe these indiscriminate attacks and doing so is consistent with the dubious legal conclusion derived earlier in the opinion, a careful analysis of the reasoning and the factual background

83. Prosecutor v. Strugar, Case No. IT-01-42-T, Trial Judgment, II 240 (Int'l Crim. Trib. for the Former Yugoslavia Jan. 31, 2005); Prosecutor v. Strugar, Case No. IT-01-42-A, Appeals Judgment, II 270 (Int'l Crim. Trib. for the Former Yugoslavia July 17, 2008); Prosecutor v. Perišić, Case No. IT-04-81-T, Trial Judgment, II 201 (Int'l Crim. Trib. for the Former Yugoslavia Sept. 6, 2011).

84. See Prosecutor v. Galić, Case No. IT-98-29-T, Trial Judgement, II 14 (Int'l Crim. Trib. for the Former Yugoslavia Dec. 5, 2003).

85. See id. \I 15.

86. See, e.g., id. II 345,410 (emphasis in original).

87. Id. (emphasis in original). 
reveals that the trial chamber finds that the defendant "at the very least" knowingly attacked civilians.

If the trial chamber notes the ICRC AP I Commentary recklessness assertion and "accepts this explanation" but does not actually apply the standard in practice, what then is the trial chamber actually intending to accomplish by "accepting" the recklessness explanation? It seems that the trial chamber is, quite understandably, attempting to derive an inherently objective standard by which to judge the fundamentally subjective matter of whether the defendant made the civilian population the object of attack. This rationale is evident from the legal conclusion of the trial chamber that, in cases wherein the defendant claims there was doubt as to the civilian nature of the persons or objects that were attacked, "the Prosecution must show that in the given circumstances a reasonable person could not have believed that the individual he or she attacked was a combatant." 88

This is the endeavor in which the trial chamber is actually engaged later in the opinion as it evaluates the defense claim that the defendant thought he was directing the sniper, artillery, and mortar attacks against military objectives but that he accidentally killed civilians. The Galic trial chamber never does conclude, to apply the explanation of the ICRC AP I Commentary it accepts, that the defendant attacks civilians "without being certain of a particular result, [but] accepts the possibility of it happening." The facts the Galic trial chamber is adjudicating are described in a later ICTY case as a "deliberate campaign ... to attack the civilian population of Sarajevo." 89 By finding that the attacks were "at the very least indiscriminate as to" the target, the Galic trial chamber is concluding that, contrary to claims by the defendant, "in the given circumstances a reasonable person could not have believed" $" 90$ the people that were attacked to be military objectives.

By engaging in this analysis, the trial chamber is simply establishing an objective method by which to assess the subjective claims by the defendant that he was not aware of the civilian nature of the people and objects that were attacked. Although the opinion "accepts" the questionable recklessness assertion reflected in the ICRC AP I Commentary without critical analysis, when applying the standard the trial chamber concludes objectively that the defendant at least knowingly attacked civilians despite the subjective assertions by the defendant to the contrary. This application of the mens rea standard exceeds the

\footnotetext{
88. Id. II $\mathbf{5 5}$ (emphasis added).

89. Perǐ̌ic, Trial Judgment $\mathbb{\llbracket} 553$.

90. Id.
} 
recklessness threshold the Galic trial chamber "accepts" from the ICRC Commentary.

\section{2. "Applying" the Galić Recklessness Test: ICTY Strugarand Perisić Cases}

After Galic established the "precedent" involving recklessness and mens rea, several ICTY opinions cite to and apply the ICRC/Galic formulation established therein. The trial chamber in Strugar, for example, considered criminal liability for the offense of shelling the civilian population with sustained artillery fire. ${ }^{91}$ In concluding its analysis, the Strugar trial chamber acknowledges the Galic test with a degree of skepticism $^{92}$ and finds that "given the acceptance of an indirect intent as sufficient to establish the necessary mens rea for murder and wilful killing [as in Galic], there appears to be no reason in principle why proof of a deliberate artillery attack on a town occupied by a civilian population" would not qualify as a criminal offense. ${ }^{93}$

In upholding the conclusions of the trial chamber, the appeals chamber in Strugar accepts the trial chamber finding that the cause of the civilian casualties and damage to civilian objects in question "was the deliberate shelling" of the civilian population by the defendants. ${ }^{94}$ The appellate decision also endorses the finding of the trial chamber that the "intent of the perpetrators of this attack was 'to target civilians and civilian objects'" and that the attacks were, therefore, criminal. ${ }^{95}$ Similar to the analytical endeavor reflected in the Galic trial chamber opinion, the Strugar appeals chamber decision employs the mens rea formulation in an attempt to objectively evaluate the defendant's subjective claim that the object of attack was a military objective. The Strugar appeals chamber decision, citing both the Galić trial chamber and appeals chamber, observes that "depending on the circumstances of the case, the indiscriminate character of an attack can be indicative of the fact that the attack was indeed directed against the civilian population." 96

91. Prosecutor v. Strugar, Case No. IT-01-42-T, Trial Judgment, If 345 (Int'l Crim. Trib. for the Former Yugoslavia Jan. 31, 2005) (characterizing the artillery attacks assessed by the tribunal in this case as being conducted "without regard to military targets" and that the attacks were performed "deliberately, indiscriminately and extensively over a prolonged time").

92. See id. II 240. The Strugar trial chamber, after acknowledging the Galić test, begins its own finding with the qualification, "Whether or not [the Galic reasoning] is so...."

93. Id. (emphasis added).

94. Prosecutor v. Strugar, Case No. IT-01-42-A, Appeals Judgment, II 272 (Int'l Crim. Trib. for the Former Yugoslavia July 17, 2008) (emphasis in original).

95. Id. (emphasis added).

96. Id. II 275. 
In any event, the deliberate shelling of civilian objects is determined objectively by the Strugar trial chamber and appeals chamber to qualify as a criminal offense. This finding corresponds with "purposeful" and "dolus directus in the first degree" on the general common law and civil law spectrum. As such, the dubious ICRC/Galić recklessness mens rea formulation is not applied in practice in the Strugardecisions.

The final example of ICTY jurisprudence to be considered here is the Perišić case, a trial chamber opinion that was rendered nearly eight years after the Galic trial decision was published. By the time of Perišić, the ICRC/Galić recklessness test had become a matter of settled law within jurisprudence of the ICTY. In fact, the trial chamber in Perišic recites the Galić finding that "wilfulness' encompasses both the notions of direct intent and indirect intent, that is, the concept of recklessness, excluding mere negligence" ${ }^{\prime 7}$ as a mere formality, while citing to Galic and the same provision of the ICRC Commentary cited in turn by Galić.

Although the Perišic trial chamber rotely recites the recklessness standard articulated by the Galić opinion, the Perišic decision does not have occasion to apply the dubious Galic recklessness formulation. This is so because, as in Strugar, the Perišic trial chamber determines that the attacks against the civilian population at issue in the case were "carried out pursuant to a deliberate campaign of attacking civilians." on the facts stipulated and adjudged in the case, the trial chamber concludes that the defendant was responsible" for "widespread or systematic attack[s] against the civilian population"100 that "resulted in the killings of hundreds of civilians and the wounding of thousands of others." Like in Strugar, the trial chamber determines that the facts being adjudicated constitute a deliberate campaign to attack

97. Prosecutor v. Perišić, Case No. IT-04-81-T, Trial Judgment, II 100 (Int'l Crim. Trib. for the Former Yugoslavia Sept. 6, 2011).

98. Id. II 538.

99. The nature of criminal liability for the defendant in Perisic, as is the case for many criminal proceedings adjudicated by international criminal tribunals, is command responsibility. It is worth noting that the Perišic appeals chamber reverses the convictions adjudged by the trial chamber because the appeals chamber determines there are insufficient grounds to conclude that the appellant exercised command responsibility for the units that engaged in the widespread attacks on civilians. See Prosecutor v. Perišić, Case No. IT-04-81-A, Appeals Judgment, II 119 (Int'l Crim. Trib. for the Former Yugoslavia Feb. 28, 2013). This reversal does not impugn the findings and conclusions that a deliberate campaign of attacking civilians took place. Rather, the appeals chamber decision simply reverses the finding that Perišic was criminally liable for the attacks on the basis of command responsibility.

100. Perišić, Trial Judgment, II 547

101. Id. I 549. 
civilians. ${ }^{102}$ As such, just as in Strugar, the degree of mens rea being factually adjudicated by the Perišic trial chamber exceeds recklessness and, instead, corresponds closely with purposeful or dolus directus in the first degree on the mens rea spectrum.

\section{E. Consolidating Recklessness and Mens Rea in ICTY Jurisprudence}

With a comprehensive assessment of recklessness as it is applied in the jurisprudence of the ICTY, what is left of the assertion from Rule 156 of the ICRC CIHL study that "international case-law has indicated that war crimes are violations that are committed" either intentionally or recklessly? At least in the context of the ICTY, this assertion is supported by the jurisprudence, but with significant limitations. The single example of "international case-law" cited by Rule 156, the Delalic trial chamber opinion, concludes that the war crime of murder can be committed in the detention context when the defendant inflicts serious bodily injury in "reckless disregard of human life" and when the victim later dies as a result of the injuries. ${ }^{103}$

A second limited context involving recklessness, as reflected in the Tadićline, involves criminal liability for participation in a joint criminal enterprise. In what is often referred to in literature ${ }^{104}$ on the topic as "JCE III," 105 an accused can be held criminally liable for an act "other than the one agreed upon in the common plan" if the "other" criminal act was "foreseeable" and the accused "willingly took that risk." 106 The foreseeability of the risk of the "other" criminal act coupled with the willingness to take that risk is described by the Tadic opinion as "dolus eventualis," or "advertent recklessness." 107 The third category of opinions applying recklessness in a specific, limited context, involves command responsibility. This specific category, established in Blaskić,

102. Id. If 320 (observing that civilians were "deliberately targeted and subjected to immense hardships that served no military purpose" during the campaign of attacks being adjudicated).

103. Prosecutor v. Delalić, Case No. IT-96-21-T, Trial Judgement, II 439 (Int'l Crim. Trib. for the Former Yugoslavia Nov. 16, 1998).

104. See, e.g., Kevin Jon Heller, JCE III, the Rome Statute, and Bashir, OpINIO Juris (Feb. 9, 2011), http://opiniojuris.org/2009/02/11/jce-iii-and-the-rome-statute; Guilia Biji, Joint Criminal Enterprise in the Jurisprudence of the International Criminal Tribunal for the Former Yugoslavia and the Prosecution of Senior Political and Military Leaders: The Krajišnik Case, 14 MAX PLANK Y.B. U.N. L. 51 (2010).

105. The abbreviation is derived from the observation that this particular aspect of the standard is the "third" category of "joint criminal enterprise" addressed in the Tadic decision.

106. Prosecutor v. Tadić, Case No. IT-94-1-A, Appeals Judgment, Il 228 (Int'l Crim. Trib. for the Former Yugoslavia July 15, 1999).

107. Id. II 220. 
concludes that a "person who orders an act or omission with the awareness of the substantial likelihood that a crime will be committed in the execution of that order, has the requisite mens rea for establishing liability."108

If these three specific, limited contexts for which ICTY jurisprudence concludes that recklessness is a sufficient mens rea to support a criminal prosecution are considered alone, the general assertion from Rule 156 of the ICRC CIHL study that "war crimes are violations that are committed" intentionally or recklessly is misleading and erroneous. Rather than such a broad assertion involving "war crimes" generally, these three categories of cases support the assertion that war crimes may be committed "recklessly" in specific, limited circumstances. A more accurate assertion, at least involving these three categories of ICTY cases, would be:

Recklessness is included in the spectrum of mens rea for war crimes in specific, limited contexts. The first is the war crime of murder in the detention context when a detainee dies as a result of serious bodily injury inflicted with reckless disregard of human life. The second involves a joint criminal enterprise when the defendant willingly participates in the criminal enterprise, a criminal act other than the one agreed upon in the common plan is committed, and commission of the "other" crime was foreseeable and the defendant willingly took that risk. The third involves command responsibility when a person who orders an act or omission does so with the awareness of a substantial likelihood that a grave breach or serious violation will be committed in the execution of that order.

This example rule is rather more limited in scope than the general recklessness assertion reflected in Rule 156 of the ICRC CIHL study. However, this example rule is a considerably more faithful and accurate application of the "international case-law" of the ICTY involving recklessness on the spectrum of mens rea that is sufficient to support a prosecution for war crimes. As the next section describes, the detainee abuse example is the only one of these three that goes on to be reflected explicitly ${ }^{109}$ in the text of the Rome Statute for the International Criminal Court.

108. Prosecutor v. Blaškić, Case No. IT-95-14-A, Appeals Judgment, II 42 (Int'l Crim. Trib. for the Former Yugoslavia July 29, 2004).

109. Detainee abuse offenses are reflected in the Rome Statute regardless of whether the detainee dies from the abuse. Inflicting serious injury in this context is sufficient to qualify as a 
What, then, of the context that could ostensibly support a general assertion related to recklessness and war crimes such as that reflected in Rule 156 of the ICRC CIHL study? The applicable offense, in the general targeting context, is the war crime of making civilian objects, individual civilians, or the civilian population the object of attack. A plain text reading of the Galic recklessness test certainly indicates that recklessness should be included on the mens rea spectrum in the general targeting context. However, the careful evaluation conducted supra of the Galic recklessness test reveals two fundamental flaws that render the mens rea articulation defective. First, the Galic trial chamber refers to the questionable "wilfulness" description in the ICRC Commentary to AP I and simply "accepts this explanation" as valid with no critical assessment of the conclusion therein. Second, neither the Galic opinion nor any subsequent ICTY opinion adopting the Galić recklessness test actually applies the test to conclude that "recklessly" attacking civilians constitutes a war crime.

All such cases, including Galic, involve conduct that is determined to constitute deliberately targeting civilians. Whether a "reckless" attack that results in incidental damage to civilian persons and/or objects would qualify as a war crime is a matter that is not actually addressed in the jurisprudence of the ICTY. Rather, the factual foundations for which the tribunal has occasion to adjudicate offenses in a general targeting context, such as the sustained and indiscriminate attack against Sarajevo, are found to be deliberate attacks against the civilian population. As such, these attacks qualify for the much higher mens rea categories of purposeful or dolus directus in the first degree or, at the very least, knowing or dolus directus in the second degree. Due to the absence of application to an actual qualifying factual scenario and to the dubious nature of the ICRC explanation the founding Galic decision accepts with no critical analysis, including recklessness on the spectrum of mens rea that is sufficient to support a war crime in the general targeting context is not supportable.

The ICTY is, of course, not the only relevant source of "international case-law" to consult in the present inquiry. This is so notwithstanding that the recklessness assertion reflected in Rule 156 of the ICRC CIHL study cites only to the ICTY-and to only one opinion from the ICTY. A separate source of international criminal law, jurisprudence of the International Criminal Court, ${ }^{110}$ is examined in the next section before

\footnotetext{
war crime, irrespective of whether the detainee later dies from the injuries that were inflicted with "reckless disregard of human life" as the Delalić form of "recklessness" would permit.

110. The ICC is certainly not the only other important source of relevant international criminal jurisprudence. The post-World War II war crimes tribunals, the International Criminal Tribunal for Rwanda, and hybrid tribunals such as the Extraordinary Chambers in the Courts of
} 
consolidating the substantive aspect of the recklessness assertion and transitioning to the procedural inquiry.

\section{F. "International Case-Law" and the International Criminal Court}

The ICTY represents an important source of "international case-law" because, among other reasons, it established the precedent for the revival of international criminal law after a period of dormancy that began when the post-World War II war crimes tribunals ended. The establishment of the ICTY and the judicial opinions that emanated from the tribunal provide a rich collection of sources to be considered by its contemporary ad hoc tribunal, the International Criminal Tribunal for Rwanda, and the international and internationalized tribunals that followed. Among the successors of the ICTY, one source of international criminal jurisprudence stands alone as the only permanent tribunal and the only international criminal tribunal established directly by a vast collection of states: the International Criminal Court.

The process by which the International Criminal Court (ICC) was established is considered in greater detail while examining the procedural aspect of the recklessness assertion in Part Two. For the present inquiry involving the substantive aspect, however, two matters involving the ICC are particularly relevant. The first is the provisions of the founding Rome Statute involving the requisite mens rea for criminal offenses established by the treaty, and the second is relevant judicial opinions of the ICC that explore the contours of these mens rea provisions.

The central mens rea component of the Rome Statute is established by Article 30, which specifies the "mental element" that is required for all crimes reflected in the treaty "unless otherwise provided." required mental element requires both "intent" and "knowledge," again "unless otherwise provided" by a specific offense. ${ }^{112}$ While there is no further explanation for the "knowledge" requirement, "intent" is considered differently based on whether the specific offense involves conduct or a consequence. For conduct, a person "has intent" when the person "means to engage in the conduct." 113 For a consequence

Cambodia and the Special Court for Sierra Leone, among others, constitute other important sources. The establishment of and judicial opinions from these sources are considered at relevant points infra in Part Two. For the present analysis of the substantive aspect of the recklessness assertion, however, these sources are of limited utility and are therefore not addressed.

111. Rome Statute, supra note 25, art. 30 (1).

112. Id

113. Id. art. $30(2)$. 
offense, a person "has intent" when the person "means to cause that consequence or is aware that it will occur in the ordinary course of events." 114 Based on this formulation, the mental element can be understood to establish "knowledge" as a baseline requirement, while "intent" constitutes an additional requirement the specifics of which depend on whether the offense in question involves "conduct" or a "consequence."

With knowledge as a baseline requirement for all offenses addressed by the Rome Statute, recklessness and the related concept of dolus eventualis are specifically excluded from the required mental element unless otherwise provided by a specific offense. This specific exclusion is no accident. As Roger Clark observes on the matter while reflecting on his experience as a delegate at the Rome Conference, "dolus eventualis and its common law cousin, recklessness, suffered banishment by consensus" during negotiations for the Rome Statute. ${ }^{115}$ Regarding the reasoning for the exclusion, Donald Piragoff and Darryl Robinson recall from their experience at the Rome Conference that delegates expressed concern that including recklessness or dolus eventualis in the general mental element provision of Article 30 "might send the wrong signal that these forms of culpability were sufficient for criminal liability as a general rule."116

In the absence of consensus in relation to adding recklessness to Article 30, the delegates negotiating the Rome Statute "decided to leave the incorporation of such mental states of culpability in individual articles that defined specific crimes or modes of responsibility." 117 This decision to exclude recklessness or dolus eventualis from the general mental element was taken notwithstanding consideration of extensive studies performed by the ICRC and submitted to the preparatory committee for the Rome Statute asserting that recklessness should be included. One such study asserts as a general observation "relevant to all offenses" described in the study that the "notion 'wilful' includes 'intent' and 'recklessness"" 118 and makes the same assertion in relation

114. Id. art. 30 (2) (b)

115. Roger S. Clark, Drafting a General Part to a Penal Code: Some Thoughts Inspired by the Negotiations on the Rome Statute of the International Criminal Court and by the Court's First Substantive Law Discussion in the Lubanga Dyilo Confirmation Proceedings, 19 CRIM. L.F. 519, 529 (2008).

116. Donald K. Piragoff \& Darryl Robinson, Article 30: Mental Element, in CoMmentary on THE Rome Statute of the International Criminal Court: Observers' Notes, Article by Article 850 (Otto Triffterer ed., 2d ed. 2008).

117. Id.

118. ICRC, Paper Prepared by the International Committee of the Red Cross on article 8, paragraph 2(b) (viii), (x), (xiii), (xiv), (xv), (xvi), (xxi), (xxii) and (xxvi), of the Statute of the International Criminal 
to several specific offenses. ${ }^{119}$ A related study submitted by the ICRC to the preparatory committee makes similar assertions regarding recklessness and war crimes, but in relation to the offense of "intentionally directing attacks against the civilian population as such" and similar targeting offenses. ${ }^{120}$

Consistent with these assertions by the ICRC, an early proposal for what would go on to become the Rome Statute included recklessness in the general mental element. The text of this draft indicates that for any specific crime that indicates the offense may be committed "recklessly," this component of the mental element is satisfied when a person "is aware of a risk that the circumstance exists or that the consequence will occur," the person "is aware that the risk is highly unreasonable to take," and the person "is indifferent to the possibility that the circumstance exists or that the consequence will occur." ${ }^{21}$ This early formulation of recklessness in the mental element is consistent with the observations reflected in the ICRC papers submitted to the preparatory committee. It is also consistent, incidentally, with the recklessness formulation derived by the ICTY Galić trial chamber opinion. However, none of the individual, specific offenses that emerged from negotiations include reference to recklessness, so that aspect of the proposed mental state article was dropped from the treaty as superfluous. ${ }^{122}$

Court, PCNICC/1999/WGEC/INF.2, Annex I, at 11 (July 14, 1999), www.legal-tools.org/doc/ d8ff04/pdf.

119. See, e.g., id. at 16-24 (in relation to subjecting a detainee to physical mutilation or to medical or scientific experiments), 24-33 (in relation to destroying or seizing the enemy's property unless such is demanded by the necessities of war), 40-46 (in relation to pillage), 46-49 (in relation to committing outrages upon personal dignity), 49-57 (in relation to rape and other forms of sexual assault), 69-75 (generally, in relation to "violations of Common Article 3 of the 1949 Geneva Conventions"), 76 (in relation to murder of all kinds), 78 (in relation to cruel treatment), 83 (in relation to committing outrages upon personal dignity), 87 (in relation to taking hostages), 121-22 (generally, in relation to "other serious violations of the laws and customs applicable in armed conflicts not of an international character").

120. See ICRC, Paper Prepared by the International Committee of the Red Cross on article 8, paragraph 2 (e), (i), (ii), (iii), (iv), (ix) and (x), of the Rome Statute of the International Criminal Court, PCNICC/ 1999/WGEC/INF/2/Add.3, Annex, at 7 (Nov. 24, 1999), www.legal-tools.org/doc/dc889c/pdf.

121. G.A., Rep. of the Preparatory Comm. on the Establishment of an International Criminal Court, U.N. Doc. A/51/22 (VOL. II), at 92 (1996).

122. See Per Saland, Intemational Criminal Law Principles, in The International Criminal Court: The Making of the Rome Statute, Issues, Negotiations, Results 189, 205 (Roy Lee ed. 1999); U.N. Diplomatic Conference of Plenipotentiaries on the Establishment of an International Criminal Court, Official Records, U.N. Doc. A/CONF.183/13 (VOL. II), 132 (2002) (summarizing the recommendation of $\mathrm{Mr}$. Saland, delegate from Sweden, to delete the reference to recklessness in the general mental element article since recklessness is "a concept which appeared nowhere else in the Statute and was therefore superfluous") [hereinafter II Rome Conference Official Records]. 
Despite extensive advocacy by the ICRC in favor of including recklessness as a component of the general mental element, then, the state delegates that negotiated the Rome Statute rejected recklessness and the related dolus eventualis.

If the text of the Rome Statute is compared with the four specific categories in which recklessness is described as part of the mens rea spectrum for war crimes in ICTY jurisprudence, the analysis reveals that two of the four categories are reflected in some form in the text of the treaty while two categories are rejected. The Delalic category of recklessness, involving murder of a detainee by inflicting serious injury in "reckless disregard of human life," is incorporated in provisions of the Rome Statute involving humane treatment for detainees. Whether or not the detainee dies from the serious bodily injury, a defendant can face prosecution for " $[w]$ ilfully causing great suffering, or serious injury to body or health"123 against a person "protected under the provisions of the relevant Geneva Convention" in an international armed conflict. ${ }^{124}$ Similarly, in the context of a non-international armed conflict, a defendant can face prosecution for inflicting "[v]iolence to life and person, in particular murder of all kinds, mutilation, cruel treatment and torture." 125 In the Delalić "recklessness" context, the accused at least knowingly, if not purposefully, inflicts serious bodily injury upon a detainee; recklessness is only a factor in a charge of murder if the detainee later dies of the injuries that were inflicted in "reckless disregard of human life." ${ }^{126}$ Pursuant to the Rome Statute, the act of "wilfully causing great suffering" in an international armed conflict (IAC) or inflicting "violence to life and person" in a non-international armed conflict (NIAC) qualifies as a war crime regardless of whether the detainee dies from the injuries. As such, the conduct that underpins the Delalic recklessness test is incorporated into the Rome Statute.

123. Rome Statute, supra note 25, art. 8(2) (a) (iii), which corresponds to the identical grave breach provisions of the 1949 Geneva Conventions and applies, by the terms of Common Article 2 of the Geneva Conventions of 1949 and by the terms of the Rome Statute, only in the context of an international armed conflict (an armed conflict between "High Contracting Parties" to the 1949 Geneva Conventions).

124. Id. art. $8(2)$. It is worth noting that, in this context and contrary to what seems to have developed as a general colloquial usage, a "protected person" is a term of art that addresses specifically the wounded and sick in the field (GC I), the wounded, sick, and shipwrecked at sea (GC II), prisoners of war (itself a defined term, addressed by GC III), and civilians in occupied territory (itself a defined term, addressed by GC IV).

125. Id. art. 8(2)(c)(i), which corresponds to Common Article 3 of the 1949 Geneva Conventions.

126. See Prosecutor v. Delalić, Case No. IT-96-21-T, Trial Judgement, II 439 (Int'l Crim. Trib. for the Former Yugoslavia Nov. 16, 1998). 
The same is arguably true in the context of the Blaskić "recklessness" component of command responsibility. A plain reading of the individual criminal responsibility provision of the Rome Statute excludes the Blaškić category of recklessness since the Rome Statute provision permits individual criminal responsibility for a commander who " $[0]$ rders, solicits or induces the commission" of a crime reflected in Article 5 of the treaty. ${ }^{127}$ This ground for individual criminal responsibility is more limited than the Blaškić recklessness category since the Blaškić recklessness formulation permits individual responsibility for a commander if she issues an order "with the awareness of the substantial likelihood"128 that subordinates will commit a serious offense in carrying out that order.

However, factual scenarios that would qualify for Blaskić recklessness are arguably incorporated in the command/superior responsibility provision of the Rome Statute. The relevant provisions of the Rome Statute permit criminal responsibility for a commander who "should have known that the forces were committing or about to commit" crimes reflected in the Rome Statute and "who failed to take all necessary and reasonable measures within his or her power to prevent or repress" the commission of the crimes ${ }^{129}$ A person in a position of authority, but who does not qualify as a "commander," can be subjected to superior responsibility for the offenses of subordinates on similar grounds. ${ }^{130}$

This mode of responsibility arguably qualifies for the Blaskić category of recklessness since a commander who "should have known" that subordinates were committing or about to commit a grave breach or serious violation would likely be found to be aware "of the substantial likelihood" that the subordinates would do so. In at least one respect, the Rome Statute version of command recklessness arguably expands upon Blaškić recklessness because the Blaškić test involves reckless orders, while the Rome Statute corollary just involves information the commander "should have known," regardless of whether the commander herself issued an order. The Blaskic category of recklessness, then, is arguably reflected in the Rome Statute, though not in exactly the same textual form that is extracted from ICTYjurisprudence.

127. Rome Statute, supra note 25 , art. 25 (3) (b).

128. Prosecutor v. Blaškić, Case No. IT-95-14-A, Appeals Judgment, II 42 (Int'l Crim. Trib. for the Former Yugoslavia July 29, 2004).

129. Rome Statute, supra note 25, art. 28(a). It is worth noting that the commander can be insulated from command responsibility for the crimes by submitting the matter to competent authorities for investigation and prosecution.

130. See id. art. $28(\mathrm{~b})$. 
One category of recklessness reflected in ICTY jurisprudence that is excluded from the Rome Statute is the "reckless" aspect of joint criminal enterprise described in Tadić. Again, Tadić recklessness, reflected in the so-called JCE III category, permits criminal liability of a person who knowingly participates in a joint criminal enterprise when the group commits an offense the defendant did not intend but was foreseeable. ${ }^{131}$ This style of recklessness is explicitly excluded from the Rome Statute provision involving individual criminal responsibility. In the context of a joint criminal enterprise, the Rome Statute only recognizes individual responsibility for participants "in the knowledge of the intention of the group to commit" a crime that is addressed by the treaty. ${ }^{132}$

Regarding the fourth category of recklessness addressed by the jurisprudence of the ICTY, the Galic recklessness test involving the general targeting context is also explicitly excluded by the Rome Statute. This result is mandated by applying the Article 30 mental element to the list of potential offenses involved in the targeting context. These offenses are, in essence, general or specific articulations of the LOAC distinction rule and, in the case of an IAC, of the proportionality rule. In the context of an IAC, the general articulation of the distinction rule prohibits "[i]ntentionally directing attacks against the civilian population as such or against individual civilians not taking direct part in hostilities" 133 and "[i]ntentionally directing attacks against civilian objects, that is, objects which are not military objectives." 134 In the NIAC context, the same prohibition is reflected as to civilian persons ${ }^{135}$ but not in general as to civilian objects. ${ }^{136}$ Articulations of the distinction rule as it applies to specific categories of persons and objects are reflected in both the IAC $^{137}$ and the

131. See Prosecutor v. Tadić, Case No. IT-94-1-A, Appeals Judgment, If 228 (Int'l Crim. Trib. for the Former Yugoslavia July 15, 1999).

132. Rome Statute, supra note 25, art. 25(3) (d) (ii) (emphasis added). For additional details regarding the exclusion of JCE III from the Rome Statute, see Heller, supra note 104.

133. Rome Statute, supra note 25, art. 8(2) (b) (i).

134. Id. art. 8(2) (b) (ii).

135. Id. art. 8(e) (i).

136. See id. art. $8(\mathrm{e})$.

137. See id. art. 8(b) (iii) (involving intentionally directing an attack against persons or objects involved in humanitarian assistance or peacekeeping operations); art. 8(b) (ix) (involving intentionally directing an attack against medical facilities or buildings of specified cultural importance); art. 8(b) (xxiv) (involving intentionally directing attacks directing attacks against personnel, places, and equipment using the distinctive emblems of the Geneva Conventions in conformity with international law). 
NIAC $^{138}$ contexts, though there are minor differences in the coverage of the two contexts.

None of the articulations of the distinction rule reflected in the Rome Statute would explicitly permit criminal liability pursuant to the ICTY Galić recklessness standard. As described supra, the Galić recklessness formulation incorporates a questionable ICRC assertion that the requisite mens rea for war crimes "encompasses the concepts of 'wrongful intent' or 'recklessness', viz., the attitude of an agent who, without being certain of a particular result, accepts the possibility of it happening." 139 As the analysis above explains, the Galic trial chamber simply "accepts this explanation" 140 with no critical analysis and applies the explanation to a targeting scenario: a sustained campaign of deliberate and indiscriminate attacks against Sarajevo.

Application of the Galic line of cases to the Rome Statute further erodes the validity of the recklessness standard described by the Galic trial chamber. This is so because all the defendants in the ICTY cases that apply the Galic recklessness test at least knowingly-and likely purposefully-directed attacks against the civilian population as such. This conduct would qualify as "intentional" pursuant to the mental element established in Article 30 of the Rome Statute and as a war crime pursuant to specific applications of the LOAC distinction rule. However, the test described by the Galic trial chamber, which is based on the questionable ICRC mens rea explanation asserting that recklessness is "part and parcel" of willfulness, is explicitly rejected by the Rome Statute.

The text of the Rome Statute is a fundamental feature of "international case-law" on the topic because the treaty describes the law that the judges of the various chambers are expected to apply. However, judicial decisions applying that text are, of course, also central to the inquiry. An early ICC judicial opinion indicated that there may be scope for expanding the requisite mental element to include something akin to dolus eventualis, ${ }^{141}$ and this development generated a degree of

138. See id. art. 8(e) (ii) (involving intentionally directing an attack against persons or objects marked with distinctive emblems recognized pursuant to international law as medical facilities or personnel); art. 8(e) (iii) (involving intentionally directing an attack against persons or objects involved in humanitarian assistance or peacekeeping operations); art. 8(e)(iv) (involving intentionally directing an attack against medical facilities or buildings of specified cultural importance).

139. See ICRC Commentary, supra note 54, II 3474.

140. See Prosecutor v. Galić, Case No. IT-98-29-T, Trial Judgement, II 54 (Int'l Crim. Trib. for the Former Yugoslavia Dec. 5, 2003).

141. See Prosecutor v. Dyilo, ICC-01/04-01/06, Decision on the Confirmation of Charges, II 352 (Jan. 29, 2007) (concluding that the general volitional element, in addition to dolus directus 
positive response among scholars. ${ }^{142}$ However, subsequent judicial opinions have clarified that the correct interpretation of Article 30 mandates that recklessness and the related dolus eventualis are excluded from the requisite mental element "unless otherwise provided" by the text of a specific offense and the elements established for the specific offense. ${ }^{143}$

None of the war crimes reflected in Article 8 of the Rome Statute explicitly permit a mens rea lower on the spectrum than that established by Article 30. However, the Elements of Crimes permit criminal liability for a perpetrator who "knew or should have known" of a particular circumstance in relation to specific war crimes. These include offenses such as improper use of a flag of truce, ${ }^{144}$ improper use of a flag, insignia or uniform of the hostile party, ${ }^{145}$ improper use of the distinctive emblem of the Geneva Conventions, ${ }^{146}$ and using, conscripting, or enlisting children. ${ }^{147}$

Although a plain reading of the text of the Rome Statute suggests that recklessness is excluded from the mental element that is applicable to war crimes (and other offenses), there is no shortage of suggestions in literature on the topic for ways that the mental element could be expanded to include recklessness. One such imaginative suggestion is to expand upon a risk formulation derived by the Lubanga trial chamber to conclude that if a person "knows there is a high risk and he nevertheless goes ahead and acts, he can fairly be said to have 'willed'

in the first and second degrees, includes "situations in which the suspect (a) is aware of the risk that the objective elements of the crime may result from his or her actions or omissions, and (b) accepts such an outcome by reconciling himself or herself with it or consenting to it (also known as dolus eventualis")).

142. See, e.g., Thomas Weigend, Intent, Mistake of Law, and Co-Perpetration in the Lubanga Decision on Confirmation of Charges, $6 \mathrm{~J}$. INT'L CRIM. JuST. 471, 482-83 (2008) (citing Gerhard WerLe, VÖLKERSTRAFRECHT ( $2 \mathrm{~d}$ ed. 2007) (analyzing the Lubanga PTC mental element discussion and observing that "the Court's more expansive interpretation of that clause certainly makes theoretical and political sense")) .

143. See, e.g., Prosecutor v. Dyilo, ICC-01/04-01/06, Decision of the Trial Chamber, II 1011 (Mar. 14, 2012) (observing that analysis of the drafting history of the Rome Statute "suggests that the notion of dolus eventualis, along with the concept of recklessness, was deliberately excluded from the framework of the Statute (e.g. see the use of the words 'unless otherwise provided' in the first sentence of Article 30")); Prosecutor v. Gombo, ICC-01/05-01/08, Decision on the Charges of the Prosecutor, IIT 367, 369 (June 15, 2009).

144. The Elements of Crimes, INT'L CrIM. COURT art. 8(2)(b) (vii)-1 (2011), https://www.icccpi.int/nr/rdonlyres/336923d8-a6ad-40ec-ad7b-45bf9de73d56/0/elementsofcrimeseng.pdf.

145. Id. art. 8 (2) (b) (vii)-2.

146. Id. art. $8(2)$ (b) (vii) -4

147. Id. art. $8(2)$ (b) (xxvi) (in the context of an IAC), art. 8(2)(e)(vii) (in the context of a NIAC). 
the consequence." 48 This suggestion speculates that "Article 30(2) (b) . . is at least a useful prop to support" such a risk-based formulation. ${ }^{149}$ However, the Lubanga appeals chamber goes on to reject the trial chamber interpretation upon which this suggestion seeks to expand. In fact, the Lubanga appeals chamber opinion characterizes the risk-based approach derived by the trial chamber as "confusing" and concludes that "reference to 'risk' should have been avoided when interpreting article 30 (2) of the Statute." 150

Yet another such proposal for expanding the Rome Statute mental element suggests a creative combination of the "unless otherwise provided" clause of Article 30 with the provision of the Rome Statute permitting application of "principles and rules of international law."151 This inventive proposal could, according to the suggestion, permit incorporation of judicial opinions from, for example, the ad hoc tribunals, to define terms such as "wilfull" and "wanton" that are borrowed from existing international law treaties and incorporated into the Rome Statute. ${ }^{152}$ A related, though less nuanced, observation bypasses the "unless otherwise provided" clause altogether and suggests direct incorporation of explanations of terms such as "wilfully" that have "consistently been interpreted by the ICTY." 153

Creative proposals such as these for expanding upon the mental element established by the Rome Statute share a common perspective: that the mental element reflected in the plain text of the Rome Statute is inconsistent with customary international law as it exists beyond the four corners of the treaty. This is especially true of suggestions that purport to incorporate seemingly preferable jurisprudence of the ad hoc tribunals, particularly of the ICTY. The role of international criminal tribunals as a source of customary international law is the primary focus

148. Weigend, supra note 142 , at 483.

149. Id.

150. Prosecutor v. Dyilo, ICC-01/04-01/06 A 5, Appeals Judgement, II 449 (Dec. 1, 2014).

151. See Rome Statute, supra note 25 , art. 21(1) (b).

152. See Gerhard Werle \& Florian Jessberger, Unless Otherwise Provided: Article 30 of the ICC Statute and the Mental Element of Crimes under International Criminal Law, 3 J. INT'L CRIM. JUST. 35, 53 (2005) (asserting that a "main source of subjective conditions of liability under customary international law is the jurisprudence of the" ad hoc tribunals and assessing examples in which the tribunals determine that recklessness is "sufficient to meet the requirements of the mental element of several" specific crimes).

153. War Crimes Research Office, Washington College of Law, Modes of Liability and the Mental Element: AnALyzing the EARly JuRisprudence of the INTERnAtional Criminal COURT 7475 (Sept. 2010), www.wcl.american.edu/impact/initiatives-programs/warcrimes/our-projects/icc-legalanalysis-and-education-project/reports/report-13-modes-of-liability-and-the-mental-element-analyzingthe-early-jurisprudence-of-the-international-criminal-court. 
of Part II. For now, it is sufficient to point out that these suggestions for expanding on the mental element established in the Rome Statute are inconsistent with the unambiguous intent of the state representatives who negotiated the text of the Rome Statute and of the states that ultimately ratified the treaty.

While certainly inventive, the suggestion that opinions from the ad hoc tribunals can be incorporated directly into the Rome Statute to clarify the meaning of seemingly ambiguous terms such as "wilful" and "wanton" constitutes a misapplication of provisions of the treaty designed to prevent assimilation of sources outside the treaty. Outside absorption of this sort is prohibited unless the text of the treaty itself is found to be ambiguous and in need of clarification. ${ }^{154}$ Careful consideration reveals that while some relevant underlying terms present a certain degree of vagueness, the Rome Statute itself does not.

It is undoubtedly true that terms such as willful and wanton are themselves ambiguous. Such terms are vestiges of central international law instruments dating back at least to the venerable Lieber Code, and in most cases the relevant instruments do not themselves clarify the meanings. ${ }^{155}$ As Roger Clark recalls from his experience with drafting the Rome Statute, many of those involved in the process "tended to fall back on" what he describes as "the previously agreed language' principle of international drafting." 156 As Clark explains the perspective of such participants:

[I]f the diplomats assembled at The Hague in 1907 (or in some other significant negotiation) used certain words, there is a strong presumption against changing them, lest "settled" law become "unsettled"! Thus, in the special part [which includes the enumerated offenses], in addition to what appear to the

154. See Rome Statute, supra note 25, art. 21.

155. See, e.g., General Orders No. 100: The Lieber Code, Instructions for the Government of Armies of the United States in the Field, art. 44 (Apr. 24, 1863) ("All wanton violence committed against persons in the invaded country, all destruction of property not commanded by the authorized officer, all robbery, all pillage or sacking, even after taking a place by main force, all rape, wounding, maiming, or killing of such inhabitants, are prohibited under the penalty of death, or such other severe punishment as may seem adequate for the gravity of the offense") (emphasis added); Agreement for the Prosecution and Punishment of the Major War Criminals of the European Axis, art. 6(b), Aug. 8, 1945, 82 U.N.T.S. 279 (describing the offense of, among others, "wanton destruction of cities, towns or villages, or devastation not justified by military necessity" as a war crime) [hereinafter IMT Statute]; GC III, supra note 69, art. 130 (replicating the grave breach provisions of the other three 1949 Geneva Conventions and describing the offense of, among others, "wilful killing" as a grave breach of GC III).

156. Clark, supra note 13 , at 314. 
casual reader to be random uses of the word "intentionally", one also finds words like "wilful", "wanton", "calculated" and "treacherously", along with some awkward uses of "unlawfully" that make life difficult in terms of applying either a specific use or a default rule. Because what was "settled" in respect of words like these turned out to be much disputed, an effort had to be made in drafting the Elements to tackle some of these issues. ${ }^{157}$

While long-standing precedent supports the inclusion of offenses such as "wilful" killing and "wanton" destruction among the war crimes enumerated in the Rome Statute, the legacy of legal instruments from which such terms are drawn does not specifically define these fundamental mens rea principles. Cautious commitment to "settled" law led the delegates involved in the Rome process to adopt the specific, though ambiguous, legacy terminology. The broad principles are settled law, even if some specific, underlying meaning is not.

Nonetheless, the ambiguity that is inherent in seemingly central mens rea terms such as "wilful" or "wanton" is of little consequence in relation to the treaty the judges of the ICC are obligated to apply. Whatever it means to "willfully" kill a victim or "wantonly" destroy property that does not qualify as a military objective, at least one thing is irrefutable: these seemingly ambiguous terms describe conduct of an alleged perpetrator. While the text of the Rome Statute invites a certain degree of ambiguity by adopting legacy mens rea terminology with no settled meaning, the universal mental element is unequivocal. Whether the offense is "wilful" killing, "wanton" destruction, or "intentionally" directing attacks against civilians, "intent and knowledge" are required ${ }^{158}$ and the perpetrator must "mean to" ${ }^{159}$ engage in the proscribed conduct.

On this application, the text of the Rome Statute is unambiguous, even if that is not the case for some of the legacy mens rea terminology incorporated by specific offenses. Article 30 functions as a closed door to explicitly exclude incorporation of interpretations of ambiguous legacy terms from outside sources rather than as an open window to invite and assimilate them. Inventive suggestions to smuggle in outside interpretations to "clarify" such legacy terminology are misguided, no matter how well-intentioned.

157. Id

158. Rome Statute, supra note 25 , art. 30 (1).

159. Id. art. 30 (2) (a). 
Such suggestions are directed at an ambiguity that does not exist because the vague terms they seek to clarify all constitute conduct, and in applying the universal mental element the Rome Statute is unequivocal. The "unless otherwise provided" clause of Article 30, then, calls for an internal assessment of the treaty and the Elements rather than an endeavor to canvass external explanations of varying trustworthiness. With neither the treaty nor the Elements providing otherwise, there is nothing to alter the default "intent and knowledge" requirement in relation to proscribed conduct such as "wilful" killing, "wanton" destruction, or "intentionally directing attacks" against civilian persons or objects.

This restrictivist conclusion is further supported by applying provisions of the Rome Statute involving identification of the applicable law. While the Court may consider and apply "established principles of the international law of armed conflict," this authorization applies only in "the second place." 60 The degree to which a questionable interpretation for "wilful" by the ICRC and a line of ICTY cases that "accepts this explanation" with no critical analysis while not actually applying it in practice constitutes an "established" principle of international law is debatable. What is indisputable is that the court is obliged to apply the text of the Rome Statute and the Elements in "the first place." 161 Absent ambiguity regarding whether "wilful" killing, "wanton" destruction, or "intentionally directing attacks" against civilians constitute conduct, or absent an internal provision of the treaty or Elements providing otherwise, the assertion that recklessness or dolus eventualis are included in the universal mental element is simply unsustainable.

In case there is any remaining room for doubt, the provision of the Rome Statute addressing the legality principle (nullum crimen sine lege) removes any remaining vestiges of uncertainty. Simply put, "[t]he definition of a crime shall be strictly construed and shall not be extended by analogy." 162 Inviting external interpretations of ambiguous terminology involving conduct, for which operation of Article 30(1) and Article $30(2)$ (a) of the Rome Statute unequivocally establish the required interpretation, is the opposite of strictly construing the mental element that applies to all offenses unless otherwise provided by the treaty or the Elements.

Likewise, construing "intent" to include "recklessness" based on an explanation by the ICRC that is accepted (but not applied) by the ICTY 
constitutes extending the mental element by analogy to the interpretations of these external sources. Such an extension would be even more implausible considering that the assertion reflected in the ICRC Commentary, which the Galic trial chamber accepts without critical scrutiny, is itself founded upon an extension by analogy. As examined supra, the analogy reflected in the ICRC AP I Commentary ${ }^{163}$ is the dubious assertion that "wilful" in the context of "making the civilian population or individual civilians the object of attack" reflected in Article 85 of AP I is conceptually and legally synonymous with a "wilful act or omission which seriously endangers the physical or mental health or integrity of any person who is in the power of a Party" reflected in Article 11 of AP I.

This analogy constitutes a category error in that the two contexts, targeting and detainee abuse, are conceptually and factually distinct-not to mention that the analogy rests on a translation ambiguity, as also examined above. If extending definitions by analogy is prohibited by operation of Article 22(2) of the Rome Statute, it would seem that doing so by incorporating a principle that itself is founded on an analogy is doubly forbidden. In any event, operation of the legality principle requires definitions to be strictly construed and proscribes extending definitions by analogy. The proposal to stretch Article 30 of the Rome Statute to accommodate recklessness, while creative, fails on both counts.

As examined infra in the analysis for Part Two, the text of the Rome Statute constitutes an extraordinarily persuasive customary prescription of grave breaches and serious violations of international law, namely genocide, crimes against humanity, and war crimes. ${ }^{164}$ This persuasiveness extends to the mental element prescription that applies, unless otherwise provided, to all offenses reflected in the Rome Statute. Excluding the Rome Statute and the judicial opinions that apply the text of the treaty from an examination of "international case-law" would defy logic. Careful evaluation of the treaty and judicial opinions that apply the treaty comprehensively repudiates the assertion that recklessness or dolus eventualis are included on the spectrum of mens rea applicable for war crimes to be adjudicated by the International Criminal Court. As such, consideration of the ICC as a component of

163. See ICRC Commentary, supra note 54, II 3474.

164. For reasons that are beyond the scope of the present inquiry, I consider that there is reason to doubt the customary status of the provisions of the Rome Statute involving the war crime of employing "bullets which expand or flatten easily in the human body" (art. 8(2) (b) (xix)) and the crime of aggression (art. 8 bis). 
"international case-law" renders the already dubious recklessness assertion as it applies to the ICTY even more implausible.

\section{G. Consolidating the Substantive Aspect}

After examining in detail relevant "international case-law" from the ICTY and ICC, the general substantive observation that "international case-law has indicated" that war crimes can be committed "intentionally" or "recklessly" is not sustainable. One of the most glaring inadequacies of this general conclusion is that the assertion treats in unitary fashion the factual scenarios that purport to apply recklessness. Murdering a detainee by inflicting serious bodily injury in "reckless" disregard of human life, as in the Delalic variety of recklessness, constitutes a separate factual and conceptual scenario than being "reckless" in a targeting context, as in Galić. Both are factually and conceptually different from the Tadić variety of "recklessness" involving JCE III. All three are factually and conceptually distinct from the Blaskic variety involving command responsibility. The circumstances in which recklessness might be considered do not constitute a unitary factual or conceptual framework. The merits of each category must be evaluated separately, as must the development and continued applicability of each.

Combining all these varieties into a consolidated conclusion that "international case-law has indicated" that recklessness in general is sufficient for a war crimes prosecution is misleading. Three varietiesDelalić, Blaskić, and Tadić-are themselves limited subsets of general categories of conduct for which recklessness is sufficient. While the Galic variety is of broader application, recklessness in this context is invoked as a method of objectively assessing the subjective claim of a defendant-and this brand is never actually applied to conclude that "recklessly" targeting civilians is a war crime. As such, drawing the conclusion that "international case-law has indicated" that war crimes can be committed recklessly is inaccurate without significant limitations. It is certainly inadequate to assert, as the ICRC CIHL study does, that the Delalić variety of recklessness, which involves the specific context of murdering a detainee by inflicting serious injury in reckless disregard of human life, supports the conclusion that war crimes in general can be committed recklessly.

Perhaps an even more grievous deficiency of the general assertion that "international case-law has indicated" that recklessness is sufficient is that it does not consider developments that have occurred since the founding opinions of the ICTY have so indicated in specific, limited 
circumstances. As examined supra, the Delalić category of recklessness derived by the ICTY does carry over to the statute for the ICC and is reflected as a war crime in the Rome Statute. The Tadic recklessness variety involving JCE III is excluded from the text of the Rome Statute. Although the Blaskić variety of recklessness involving command responsibility seems to be excluded by the text of the Rome Statute, this variety may be indirectly applicable depending on the specific factual scenario involved in a particular case.

As for the assertion that recklessness is a viable component on the spectrum of mens rea applicable for war crimes in the general targeting context pursuant to the jurisprudence of international criminal tribunals, the contention simply does not withstand scrutiny. This particular form of recklessness is based on a questionable ICRC explanation that was accepted by the Galic ICTY trial chamber with no critical assessment and never actually applied in practice to conclude that recklessness is sufficient. ${ }^{165}$ This form of recklessness was later explicitly discarded by the state delegates that negotiated the Rome Statute. Despite an early ICC judicial opinion indicating that there may be room for expanding the mental element reflected in the treaty to include recklessness or dolus eventualis, subsequent ICC jurisprudence has explicitly rejected this possibility. ${ }^{166}$ Based on a close and detailed inspection, continuing to assert that "international case-law" indicates that recklessness or the related dolus eventualis are included on the spectrum of mens rea applicable for war crimes in a general targeting context is, at the very best, ill-informed.

The inquiry thus far has been confined to the substantive aspect of the recklessness assertion-exploring whether "international caselaw" truly does indicate, in general, that recklessness is a sufficient mens rea to support a war crimes prosecution as a matter of customary international law. While the answer to that inquiry is a resounding "no," this investigation does not address a fundamental issue with much broader implications. From a procedural perspective, what is the role of "international case-law"-or, to be more precise, the jurisprudence of international criminal tribunals-as a source of customary international law? That role, and the relationship between international criminal tribunals and states, provides the central focus for Part Two.

165. See supra Section III.D.1.

166. See Prosecutor v. Dyilo, ICC-01/04-01/06, Decision on the Confirmation of Charges, supra note 141; Prosecutor v. Dyilo, ICC-01/04-01/06, Decision of the Trial Chamber, supra note 143. 


\section{Part Two: Procedural Assessment and the "Designate and Extend" ModeL}

The conclusion that "international case-law" indicates that recklessness is a component of the mens rea for war crimes only in specific, limited circumstances as a matter of customary international law is useful in relation to that specific substantive matter. While this substantive conclusion is important in the context of characterizing and adjudicating offenses that occur during armed conflict, the recklessness question implicates an issue of much broader concern. If assertions that recklessness is sufficient as a matter of customary international law frequently, perhaps even exclusively, rely on jurisprudence of international criminal tribunals for support, the presently unsettled role of these tribunals as a source of international law must be established. Clarifying that role and the relationship between international criminal tribunals and states is the central endeavor for Part Two.

Although Rule 156 of the ICRC CIHL study invites this procedural matter by relying exclusively on "international case-law" in support of the recklessness assertion, the ICRC is not alone. For example, in criticizing the implied conclusion of the U.S. military following the Kunduz airstrike that recklessness is excluded from the mens rea spectrum applicable for war crimes, Adhil Ahmad Haque points exclusively to jurisprudence from the ICTY as evidence of customary international law before challenging, "[i]f the [U.S.] Army rejects the ICTY's understanding of customary international law then it should explain why."167 Haque goes on to explain his understanding that there is no reason to believe that the "Rome Statute casts doubt on the ICTY"s rulings, or perhaps reflects a narrowing of customary international law." 68

When addressing the substantive inquiry regarding recklessness and war crimes, this perspective that judicial opinions from the ICTY function to establish the parameters of customary international law and that it is incumbent upon other entities to comply with this "law" is rather popular. Antonio Cassese, for example, lamenting the Rome Statute exclusion of recklessness from the mental element for war crimes, asserts that "current international law must be taken to allow for recklessness" to be included. ${ }^{169}$ By failing to comply with "current

167. Haque, supra note 7 (emphasis added).

168. Id.

169. Antonio Cassese, The Statute of the International Criminal Court: Some Preliminary Reflections, 10 EUR. J. INT'L L. 144, 154 (1999). Although Cassese does not refer directly to jurisprudence of the ICTY in this observation that the Rome Statute should align with "current international law," the inference can be drawn from the fact that Cassese was at the time the president of the ICTY 
international law," Cassese concludes that "on this score the Rome Statute marks a step backwards with respect to lex lata." ${ }^{770}$ Knut Dörmann, who was then a legal advisor for the ICRC and has been the Head of the Legal Division for the ICRC since 2007, offered a similar assessment of the fledgling Rome Statute when he observed, "[i]t will be up to the future judges of the ICC to bring [ICTY] case law into line with the [mental element] rule in article 30 " of the treaty. ${ }^{171}$

These and similar observations inspire a host of fundamental questions that do not appear to have satisfactory answers in the contemporary theory and practice of international law. For example, when it comes to defining international law, does jurisprudence from the ICTY truly establish the standard against which other entities should be measured for compliance? Or should the Rome Statute take precedence because it is later in time than the statutes for the ad hoc tribunals? What conclusions should be drawn regarding the status of a particular "rule" of international law if judicial opinions from the ICTY, for example, are inconsistent with those from the ICC or, perhaps, with the Rome Statute itself? For that matter, how can international criminal tribunals be said to establish international law in the first instance when this is traditionally considered to be within the exclusive purview of states?

As the observations and questions above demonstrate, the emergence of contemporary international criminal law, beginning with the International Military Tribunal and the Subsequent Nuremburg Proceedings in the aftermath of World War II, has complicated the canonical role of states as the sole primary source of international law. What has traditionally been considered the exclusive domain of states is no longer a matter beyond contestation. After all, before the establishment of international criminal tribunals, states alone possessed the authority to adjudicate criminal offenses.

and the factual scenario from which he draws, "shelling a town" while taking a "high and unjustifiable risk that civilians will be killed," is consistent with a central factual basis for the ICTY Kupreskić case that was before Cassese's trial chamber when the Article cited by this footnote was published.

170. Id.

171. Knut Dörmann, War Crimes under the Rome Statute of the International Criminal Court, with a Special Focus on the Negotiations on the Elements of Crimes, 7 MAX PLANCK Y.B. U.N. L. 341, 353 (2003). The observation from the cited source represents a direct quote from an article Mr. Dörmann submitted to the preparatory committee tasked to draft the elements of crimes for the Rome Statute. See Knut Dörmann, Preparatory Commission for the International Criminal Court: The Elements of War Cnimes, 839 INT'L REV. RED CROSS (Sept. 30, 2000), www.icrc.org/en/doc/resources/ documents/article/other/57jqqd.htm. 
The uncertainty regarding the precise relationship between states and international criminal tribunals evokes the ongoing debate between the so-called "traditional" and "modern" approaches to categorizing sources of international law. The traditional role of states as the sole primary source of international law is described in the Statute for the International Court of Justice ${ }^{172}$ and has since been famously articulated by the North Sea Continental Shelf Cases opinion of that court ${ }^{173}$ and, much more recently, been adopted by the International Law Commission. ${ }^{174}$ The articulation is so widely recognized that it scarcely requires recapitulation. However, for the purpose of juxtaposing it against the emerging so-called "modern" approach, the widely-cited articulation from the North Sea Continental Shelf opinion observes that customary international law is derived from a practice that is "extensive and virtually uniform" among states, particularly those whose "interests are especially affected," and that states must "show a general recognition that a rule of law or legal obligation is involved." this approach, the practice of states constitutes the sole primary source of customary international law, while judgments of international criminal tribunals and the writings of highly qualified publicists represent subsidiary sources.

The perspective that decisions of international criminal tribunals can be considered as a primary source of law constitutes a two-step application of the so-called "modern" approach to identifying sources of international law. The first step is to emphasize the normative value of one component or the other, general state practice or opinio juris, of the dual requirements of what proponents describe as the "traditional" approach. The second step is to characterize opinions of international criminal tribunals as being on the same footing as state practice in terms of authority to prescribe rules of customary law.

This application of the so-called "modern" approach can be appealing if, for example, there seems to be a relative scarcity of state practice from which to draw. Cassese, writing an ICTY trial chamber opinion, implements this approach when canvassing state practice in relation to reprisals against civilians in armed conflict. Finding no state practice in

172. See Statute of the International Court of Justice, June 26, 1945, art. 35, 59 Stat. 1055, 33 U.N.T.S. 933.

173. See North Sea Continental Shelf (Ger./Den.; Ger./Neth.), Judgement, 1969 I.C.J. 3, g[ 74 (Feb. 20)

174. Int'l Law Comm'n, Rep. on the Work of Its Seventieth Session, U.N. Doc. A/73/10, at 130 (2018) (specifically Conclusion 2, but generally throughout), https://undocs.org/en/A/73/10.

175. North Sea Continental Shelf, supra note 173, II 74. 
favor or against the prohibition, ${ }^{176}$ the analysis considers instead what is deduced to be the opinion of states on the matter. ${ }^{177}$ While the stated conclusion that extensive and virtually uniform state opinion supports the prohibition is questionable, ${ }^{178}$ the process of emphasizing what is described as opinio juris at the expense of state practice is a cornerstone of the so-called "modern" approach to customary international law.

The second step, placing opinions of international criminal tribunals on equal footing with state practice, is a natural extension of the endeavor to fill a perceived gap in state practice. In this application, international criminal tribunals can be characterized as state proxies. This characterization seems reasonable because legitimacy to adjudicate criminal offenses has heretofore been the sole purview of states, and by one mechanism or another the tribunals are created by states to legitimately perform this adjudicative role.

In this context, resorting to opinions of international criminal tribunals to address a perceived scarcity of state practice from which to draw in articulating rules of customary international law is not the only appeal. Observations extracted from opinions of international criminal tribunals can also be alluring if canvassing existing state practice yields an unpalatable result. As Allison Marston Danner thus contends, "international judicial lawmaking is particularly appropriate when the underlying treaties are anachronistic, and there exists little possibility for their revision in a diplomatic setting." 179

This purported general expansion beyond the traditional approach is particularly salient in the specific context of international criminal law. The ostensive prescriptive function of international criminal tribunals has led to the observation that the "lawmaking process [in international law] through judicial interpretation is ongoing at the ad hoc tribunals and started in 2002 at the ICC." 180 Such a "lawmaking" authority is required in the present context if "international case-law" is to be

176. Prosecutor v. Kupreškic, Case No. IT-95-16-T, Judgment, II 527 (Int'l Crim. Trib. for the Former Yugoslavia Jan. 14, 2000).

177. See id. II 527-33.

178. See, e.g., Willam H. Boothby, The LaW of TARgeting 63 (2012) (citing a scholarly article and making note of indications of potentially contrary perspectives of the United Kingdom, Italy, and the United States); Office of Gen. Couns., DeP'T OF Def., LAw OF WAR MANuAl II 18.18.3.4. (3d ed. 2016) (citing examples of perspectives of states such as the United Kingdom, Egypt, Germany, Italy, and France in support of the U.S. perspective that the prohibition against reprisals reflected in AP I does not constitute a rule of customary international law).

179. Allison Marston Danner, When Courts Make Law: How the International Criminal Tribunals Recast the Laws of War, 59 VAND. L. REV. 1, 62 (2006).

180. VAN SLIEDREGT, supra note 19, at 4 (emphasis added). 
the sole source relied upon in support of the assertion that recklessness is a sufficient mens rea to support a war crimes prosecution as a matter of customary international law. If international criminal tribunals truly do possess "lawmaking" authority and can purportedly join states as a primary source of customary international law, how is it that the baton is passed from states to tribunals? What exactly is the relationship between international criminal tribunals and states?

In the endeavor to bring clarity to this relationship, the analysis in Part Two offers a new way to conceptualize the role of international criminal tribunals. The "designate and extend" model established and applied herein describes the relationship between states and international criminal tribunals and thereby offers a degree of order and clarity that seems elusive in present scholarship. After exploring the merits and limitations of the current popular model, the principalagent relationship between states and tribunals, the specific contours of the new designate and extend approach are explained. With the analytical framework of the designate and extend model described, existing "international case-law" is applied to the approach in the endeavor to clarify the role of international criminal tribunals as a source of international law. Before describing and applying the new approach to conceptualizing the role of international criminal tribunals, the inquiry turns now to address the prevailing principal-agent model.

\section{A. Principal-Agent Method of Describing Relationship Between States and Tribunals}

One popular suggestion for articulating the method by which the lawmaking baton is passed from states to international criminal tribunals is to consider the tribunals to be delegates exercising judicial authority on behalf of states. While this is not the only conceptual model utilized to describe the relationship between states and tribunals, ${ }^{181}$ the principal-agent relationship is regarded as an obvious truth in much of the existing literature from scholars $^{182}$ and advocacy

181. See, e.g., Carsten Stahn, Response: The ICC, Pre-Existing Jurisdictional Treaty Regimes, and the Limits of the Nemo Dat Quod Non Habet Doctrine - A Reply to Michael Newton, 49 VAND. J. TrANSNAT'L L. 443, 448 (2016) (describing an omnipresent universal jurisdiction of the ICC that a state "merely activates" by virtue of ratifying the Rome Statute).

182. See, e.g., Leslie Vinjamuri, The International Criminal Court: The Paradox of its Authority, in International Court Authority 331, 335 (Karen J. Alter, Laurence R. Helfer \& Mikael Rask Madsen ed., 2018) (observing that when states ratify the Rome Statute they are "in effect voluntarily agreeing to delegate authority ... to the ICC" to prosecute the relevant crimes); Michael A. Newton, How the International Criminal Court Threatens Treaty Norms, 49 VAND. J. TRANSNAT'L L. 371, 374-75 (2016) (“ICC jurisdiction flows exclusively from the delegation of a 
groups. ${ }^{183}$ The prevalence of this principal-agent model is possibly best captured by the observation that " $[\mathrm{c}]$ onceiving of international courts in terms of delegating authority [from states] is perhaps the main way international courts are discussed in the American political science literature." $" 84$

This prevalent model could ostensibly explain the conceptual mechanism by which international criminal tribunals become infused with "lawmaking" authority. If states, as principals, have delegated their authority to international tribunals, as agents, to allow the tribunals to exercise judicial authority in situations in which states find it difficult to do so, perhaps asserting that the decisions of these "agents" represent a primary source of customary law should be rather uncontroversial. This would permit, for example, the ICRC to rely solely on "international case-law" as authority to support the assertion that recklessness is a sufficient mens rea to support a war crimes prosecution.

It is certainly conceptually appealing to characterize the role of states and international organizations such as the United Nations in creating international or internationalized tribunals ${ }^{185}$ as delegating

State Party's sovereign jurisdictional power."); Elena Kantorowicz-Reznichenko, The Enforcement of International Law, in The Changing Global Order 361, 379 (Madeleine O. Hosli \& Joren Selleslaghs ed., 2020) (explaining the "realist's perspective [that] States will delegate authority to an international institution only if it reflects the balance of powers"); Dapo Akande, The Jurisdiction of the International Criminal Count over Nationals of Non-Parties: Legal Basis and Limits, $1 \mathrm{~J}$. INT'L CRIM. JuST. 618, 624-25 (2003) ("States have been particularly willing to delegate jurisdiction in respect of crimes deemed to be of concern to the international community and where broad jurisdictional measures are needed to prevent and repress those crimes.").

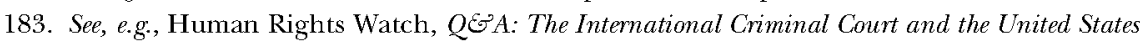
(Sept. 2, 2020), www.hrw.org/news/2019/03/15/qa-international-criminal-court-and-unitedstates (describing the premise that states are "simply delegating their authority to prosecute certain grave crimes committed on their territory to an international court" by ratifying the Rome Statute as a "basic and well established principle of international law"); Int'l. Comm. of the Red Cross , Establishment of an International Criminal Court, LG 2000-107-ENG (Oct. 19, 2000), www.icrc. $\mathrm{org} / \mathrm{en} / \mathrm{doc} / \mathrm{resources} /$ documents/statement/57jqn4.htm (asserting that there is "no doubt about the right of a State to delegate" authority to prosecute certain crimes to an "international tribunal").

184. Karen J. Alter, Do International Courts Enhance Compliance with International Law?, 25 REV. ASIAN \& PAC. STUD., 51, 58-59 (2003).

185. The distinction between "international" such as the ICC, ICTY, and ICTR, and "internationalized" (or "hybrid") tribunals is particularly relevant when considering or assessing how the different categories of tribunals are formed and pursuant to what legal basis they function. However, the present inquiry focuses primarily on international (rather than internationalized) tribunals because of the inherently independent exercise of adjudicative and enforcement jurisdiction extended to the international tribunals. The procedural significance of selected hybrid tribunals is examined infra, but the present inquiry is focused predominantly on international tribunals. 
state authority to such tribunals. After all, international criminal tribunals do carry out an inherent state function by adjudicating allegations of criminal conduct. Such an arrangement would support the observation that "international judicial lawmaking may be the truth of international politics that cannot be named" because "states simply do not want to acknowledge that international courts make international law." 186 This principal-agent model, however, is problematic for at least three distinct reasons.

The first factor to be addressed here that renders the principal-agent model conceptually and factually unsatisfactory is the degree of independence the "agent" tribunals are expected to exercise after being established by the "principal" states. The establishing statutes of the ICTY, ${ }^{187}$ International Criminal Tribunal for Rwanda (ICTR), ${ }^{188}$ and ICC, ${ }^{189}$ for example, of course confirm that it is the tribunal and not the relevant collection of states that are empowered to adjudicate offenses brought before the tribunal. A survey of perspectives proffered by several representatives of states while deliberating establishment of the ICTY ${ }^{190}$ and drafting the Rome Statute of the ICC $^{191}$ provides useful

186. Danner, supranote 179, at 47 (emphasis added).

187. See Statute of the International Criminal Tribunal for the Former Yugoslavia, S.C. Res. 827, art. 1, U.N. Doc. S/RES/827 (May 25, 1993).

188. See Statute of the International Criminal Tribunal for Rwanda, S.C. Res. 955, art. 1, U.N. Doc. S/RES/955 (Nov. 8, 1994).

189. See Rome Statute, supra note 25, art. 1.

190. See, e.g., U.N. SCOR, 48th Sess., 3217th mtg. at 23 (statement of New Zealand, observing that the "task [of the ICTY] is to apply independently and impartially the rules of customary international" and that it "must be left to carry out its work until it has discharged its mandate under its Statute or until the Council decides that its work shall be brought to an end," and statement of Japan, observing that it is incumbent on the Security Council "to ensure that the Tribunal is independent and neutral and that it reflects the universal authority of the United Nations"), at 28 (statement of Morocco, observing that "the effectiveness and credibility of the Tribunal, which must be independent and neutral, will depend on" being adequately supported and resourced by the U.N. and member states), at 39-40 (statement of Spain, observing that "the Tribunal does appear as a clearly independent organ”), U.N. Doc. S/PV.3217 (May 25, 1993) [hereinafter S/PV.3217].

191. See, e.g., U.N. GAOR, 183d Sess., 13th plen. mtg., at 63 (summarizing the remarks of the President of the Rome Conference, observing that the "expectations of mankind must not be disappointed" and, to that end, that the ICC "must be universal and independent so that it could prosecute the most serious crimes impartially and efficiently"), at 66 (summarizing the remarks of the delegate from Norway, proclaiming the commitment of Norway to the "establishment of a strong and independent court"), at 67 (summarizing the remarks of the delegate from Japan, emphasizing that the ICC "should be a strictly independent and impartial judicial organ of the international community, independent of any political influence, and its judgements should be given exclusively on the basis of law"), U.N. Doc. A/CONF.183/13 (Vol. II) (2002). 
insight in support of the resolute commitment to the judicial independence of the tribunals thus created. If the tribunals are intended to adjudicate offenses in a manner that is independent from the interests of states, the conception of tribunals as "agents" of the "principal" states seems rather untenable.

A second, related factor that erodes the legitimacy of the principalagent construct is the persistent reluctance of several specially affected states to submit to the jurisdiction of the "agent" tribunals. The ongoing saga ${ }^{192}$ of the application by the ICC Prosecutor to investigate allegations of war crimes committed in Afghanistan is a conspicuous illustration of the sovereignty and jurisdiction concerns expressed by many specially affected states-here, the United States in particularwith submitting to the authority of an international criminal tribunal. Vociferous opposition expressed by relevant officials in the previous U.S. administration ${ }^{193}$ is set against the backdrop of legislation, pejoratively referred to as the "Hague Invasion Act," that has granted standing domestic authority for the president to use "all means necessary and appropriate to bring about the release of" any U.S. service member "who is being detained or imprisoned by, on behalf of, or at the request of the International Criminal Court" since the legislation was enacted in $2002 .^{194}$

192. See Situation in the Islamic Republic of Afghanistan, ICC-02/17 OA4, Judgment on Appeal Against Decision on Authorisation of an Investigation (Mar. 5, 2020), https://www.icccpi.int/CourtRecords/CR2020_00828.pdf (authorizing the Prosecutor to commence an investigation in relation to alleged crimes committed on the territory of Afghanistan).

193. See, e.g., Exec. Order No. 13,928, 85 Fed. Reg. 36, 139 (June 11, 2020), https://www. govinfo.gov/content/pkg/FR-2020-06-15/pdf/2020-12953.pdf (observing that the "United States is not a party to the Rome Statute, has never accepted ICC jurisdiction over its personnel, and has consistently rejected ICC assertions of jurisdiction over United States personnel" while directing imposition of economic sanctions and travel restrictions on persons, businesses, or organizations assisting with the investigation or prosecution of U.S. personnel); Press Statement, Michael R. Pompeo, Sec'y of State, ICC Decision on Afghanistan (Mar. 5, 2020), www.state.gov/icc-decisionon-afghanistan (describing the ICC as an "unaccountable political institution, masquerading as a legal body" and reinforcing that the United States "will take all necessary measures to protect [its] citizens from this renegade, so-called court"); John Bolton, former National Security Advisor, Protecting American Constitutionalism and Sovereignty from International Threats (Sept. 10, 2018), reprinted in National Security Adviser John Bolton Remarks to Federalist Society, LAWFARE (Sept. 10, 2018, 2:43 PM), www.lawfareblog.com/national-security-adviser-john-bolton-remarksfederalist-society (expressing pride in leading the 2002 effort to "un-sign" the Rome Statute and asserting, among other objections to the tribunal, that the ICC "unacceptably threatens American sovereignty and U.S. national security interests").

194. 22 U.S.C. $\$ 7427$ (2014). For context, the official title of the legislation is "Authority to free members of the Armed Forces of the United States and certain other persons detained or imprisoned by or on behalf of the International Criminal Court." 
The United States is, of course, by no means the only state that routinely engages in foreign military activities and has expressed reluctance to submit to the jurisdiction of the ICC. Representatives of Israel, ${ }^{195}$ Russia, ${ }^{196}$ and China, ${ }^{197}$ for example, have expressed similar concerns. If the only permanent international criminal tribunal with the potential to subject officials of such states to criminal process and to enforce a criminal sanction imposed were truly an "agent" of the "principal" states that have ratified the Rome Statute, one would suppose that these specially affected states would have no reason to be concerned with the prospect of submitting to the jurisdiction of the "agent" tribunal. Reasonable opinions may certainly vary regarding whether this reluctance to ratify is valid based on the complementarity principle instituted by the Rome Statute. Varying opinions notwithstanding, the fact remains that a number of significant states remain unwilling to voluntarily become subject to the jurisdiction of the ICC, and this reluctance would not be a factor if the tribunal were truly an "agent" of the states that ratify the Rome Statute.

The final, and perhaps most significant, factor to be addressed herein suggesting the miscalculation of the principal-agent model is that the construct fails to explain how it is that judicial opinions from the "agent" tribunals could become binding on the "principal" states as a matter of customary international law. If customary international law is supposed to be binding on all states, excluding persistent objectors (except that peremptory norms cannot be the subject of objection), what conceptual or legal mechanism operates to bind the principal to

195. Times of Israel Staff \& Agencies, Netanyahu Says ICC Decision not to Probe U.S. Troops Bodes Well for Israel, TIMES OF ISRAEL (Apr. 14, 2019), www.timesofisrael.com/netanyahu-says-iccdecision-not-to-probe-us-troops-bodes-well-for-israel (reporting that PM Benjamin Netanyahu described as "absurd" the idea that the ICC would investigate American or Israeli troops because such action would represent "the opposite of the original purpose of the International Criminal Court").

196. Statement by the Russian Foreign Ministry, THE Ministry of Foreign Affairs of THE Russian FEDERATION (Nov. 16, 2016), www.mid.ru/en/main_en/-/asset_publisher/G51iJnfMMNKX/content/ id/2523566 (conveying the intent to withdraw the signature of the Russian Federation from the Rome Statute while expressing that the government "can hardly trust the ICC" after the tribunal indicated the intent to investigate potential offenses committed in Georgia in 2008).

197. U.N. GAOR, 74th Sess., 25th plen. mtg. at 22-23, U.N. Doc. A/74/PV.25 (Nov. 4, 2019) (asserting that the "Pre-Trial Chamber [of the ICC] has unduly expanded its jurisdiction to the point of blurring the boundaries between States parties and non-States parties" and expressing the hope of China that the ICC "will carefully exercise its authority, in strict accordance with the Rome Statute, to ensure that its judicial activities are in line with basic principles of international law"). 
opinions of the agents? Absent a satisfactory answer to this question, the principal-agent model is left wanting.

One potential solution to this puzzle could be to borrow from the law of agency in basic contract law. As Allison Danner observes, "[p]rincipals often delegate the task of completing contracts (or lawmaking, in the context of a court) to agents." ${ }^{198}$ As such, according to Danner, "[t]hat international courts engage in lawmaking is unsurprising to those who study principal-agent relationships."199

While there can be no doubt that states expressly establish international criminal tribunals to adjudicate grave breaches and serious violations of international law, there is no evidence to suggest that states either expressly or impliedly consent to allowing international criminal tribunals to formulate law that would be binding on states. To carry the questionable contract law analogy to conclusion, states do not express or imply a grant of such authority, and there is no conduct of states that could lead to a reasonable belief of such a grant and thereby support a claim of apparent authority. The assertion that the "lawmaking" capacity of international criminal tribunals should be "unsurprising to those who study principal-agent relationships" is, at best, doubtful absent evidence that states intend to be bound by "law" that is formulated by the "agent" tribunals.

Considering "international case-law" to be a suggestion of potential customary law that states may or may not adopt would be a way to make the principal-agent construct more accurate conceptually. That would essentially be a practical application of what proponents of the "modern" approach to describing sources of customary international law would describe as the "traditional" model, and the jurisprudence would thus be confirmed to be a subsidiary source of law. However, this is not how "international case-law" is utilized in existing literature that applies the principal-agent model. Observations such as those by Cassese that "current international law must be taken to allow for recklessness" to be included in the mental element of the Rome Statute ${ }^{200}$ and of Dörmann that it is "up to the future judges of the ICC" to bring the mental element applied by that tribunal "in line" with opinions from the ICTY ${ }^{201}$ do not treat jurisprudence from the ICTY as a subsidiary source. The same is true for the related observation that opinions from

198. Danner, supra note 179 , at 48 .

199. Id.

200. Cassese, supra note 169.

201. Dörmann, supra note 171. 
international criminal tribunals set the standard to which states must adhere in order to comply with customary international law. ${ }^{202}$

The conventional application of the principal-agent construct utilizes "international case-law"-at least, the particular strain that supports the preferred outcome-as a source that is capable of independently establishing the standard with which other tribunals, and even states, must comply as a matter of customary law. This represents a "lawmaking" function that exceeds status as a mere subsidiary source. However, proponents of this application fail to address a stark conceptual deficiency inherent with this formulation. In some manner, jurisprudence of the "agent" tribunals must be demonstrated to be capable of binding the "principal" states even though states have not expressed or implied the extension of such authority to international criminal tribunals. Absent a satisfactory explanation, the "principal-agent" model of the "lawmaking" capacity of international criminal tribunals is rendered conceptually inadequate.

If the popular principal-agent model is demonstrably deficient for at least the three reasons examined above, what, then, is the exact nature of the relationship between states and international criminal tribunals? That answer requires a more nuanced application of the types of jurisdiction exercised by states as well as a more precise treatment of the inefficiencies inherent in international law that international criminal tribunals are created to address than the prevailing principal-agent model employs. The result is the designate and extend model that is described in the next section.

\section{B. Designate and Extend Model of Describing Relationship Between States and Tribunals}

The endeavor to develop a more conceptually accurate model to describe the relationship between states and international criminal tribunals begins by recalling the three general types of jurisdiction exercised by states. While elementary, a brief summary is useful since the designate and extend model established herein applies the different

202. See, e.g., Letter from Sarah Margon, supra note 1, at 2; Haque, supra note 7; Sarah Knuckey, Anjli Parrin \& Keerthana Nimmala, US Government Concludes no "War Crimes" in Kunduz Strike, But Fails to Explain Why, JUST SECURITY (Apr. 29, 2016), www.justsecurity.org/30831/ government-concludes-war-crimes-kunduz-strike-fails-explain (challenging the conclusion from the U.S. Central Command summary memorandum regarding the Kunduz attack that recklessness is not included on the spectrum of mens rea for war crimes by citing (but not identifying) "a number of international cases" that "have found that 'recklessness" or "indirect intent' could satisfy the intent requirement"). 
categories of jurisdiction separately. For this purpose, the American Law Institute Restatement (Fourth) of Foreign Relations Law provides a succinct summary from which to draw. The Restatement describes prescriptive jurisdiction as "the authority of a state to make law applicable to persons, property, or conduct"; ${ }^{203}$ adjudicative jurisdiction as "the authority of a state to apply law to persons or things, in particular through the processes of its courts or administrative tribunals"; ${ }^{204}$ and enforcement jurisdiction as "the authority of a state to exercise its power to compel compliance with law."205

The second relevant factor in the relationship between states and international criminal tribunals that is helpful to recall is the specific inefficiencies generated by international law that the tribunals are created to address. One common theme, to end impunity for violations of the most egregious violations of international law, animates the aspiration of the entire body of international criminal law. This aspiration is expressed in the establishing charters for the International Military Tribunal (IMT) ${ }^{206}$ and the $\mathrm{ICC}^{207}$ as well as in the Security Council resolutions creating the ICTY, ${ }^{208}$ ICTR, ${ }^{209}$ and hybrid tribunals. ${ }^{210}$

The pernicious impunity that stimulated the development of contemporary international criminal law with the establishment of the IMT

203. Restatement (Fourth) of Foreign Relations LAW $\$ 401$ (a) (AM. L. InST. 2018).

204. Id. $\$ 401$ (b).

205. Id. $\$ 401(\mathrm{c})$.

206. IMT Statute, supra note 155, pmbl. (expressing the "intention that War Criminals shall be brought to justice" and permitting the IMT to exercise jurisdiction "without prejudice" to states that will adjudicate offenses in the "case of war criminals whose offences have no particular geographical location").

207. Rome Statute, supra note 25, pmbl. (expressing the determination "to put an end to impunity for the perpetrators of" crimes that are characterized as "unimaginable atrocities that deeply shock the conscience of humanity").

208. S.C. Res. 827, pmbl. (May 25, 1993) (expressing the determination to "put an end" to atrocity crimes committed in the territory of the former Yugoslavia and "to take effective measures to bring to justice the persons who are responsible for" the crimes).

209. S.C. Res. 955, pmbl. (Nov. 8, 1994) (expressing the same determination as indicated in the previous footnote but in relation to offences committed in Rwanda).

210. See, e.g., S.C. Res. 1272, pmbl. \& art. 1 (Oct. 25, 1999) (expressing "concern at reports indicating that systematic, widespread and flagrant violations of international humanitarian and human rights law have been committed in East Timor" and "stressing that persons committing such violations bear individual responsibility" while establishing the United Nations Mission in East Timor, which is "empowered to exercise all legislative and executive authority, including the administration of justice"); S.C. Res. 1315, pmbl. (Aug. 14, 2000) (expressing deep concern regarding "the very serious crimes committed within the territory of Sierra Leone against the people of Sierra Leone and United Nations and associated personnel and at the prevailing situation of impunity"). 
after World War II and that continues as the animating spirit for the body of law today is created by discernible inefficiencies in contemporary international law. The exalted value of the territorial integrity of states, which permeates international law but takes elemental textual form in Article 2(4) of the UN Charter, is the wellspring of the primary inefficiency. If a grave breach or serious violation of international law is committed at a time and in a place where there is no state that is able and willing to adjudicate the offense, there exists little prospect that the alleged perpetrator will face justice. The same is true if a national court could adjudicate the offense but the alleged perpetrator is located in the territory of a state that is unwilling or unable to institute a genuine inquiry involving the alleged offenses. Absent some legitimate internationalized mechanism, the dominant value of the territorial integrity of states frustrates the aspiration to end impunity for perpetrators of grave breaches or serious violations of international law.

It is the desire to correct this discernible inefficiency, created by the tension between the value of territorial integrity and the aspiration to end impunity, that constitutes the raison d'être of international criminal law. When this inefficiency is collated with the three general categories of jurisdiction exercised by states, the designate and extend model of describing the relationship between states and international criminal tribunals takes shape. Applied to the categories of jurisdiction, the inefficiency is extant only in the adjudicative and enforcement categories. This central observation mandates that prescriptions of international law be treated differently from endeavors to adjudicate offenses or enforce judicial orders rendered pursuant to the prescribed law. The designate and extend model accomplishes this mandate, while the prevailing principal-agent approach fails to do so.

1. Establishing the Parameters of the Designate and Extend Model

Regarding prescriptive jurisdiction, the relevant collection of states $^{211}$ acts to "designate" the law to be applied by the international tribunal being established. The collection of states does not require the

211. For the IMT, the "relevant collection of states" was initially "the Signatories" (U.K., United States, France, and USSR) and it was subsequently these states, plus the collection of states reflected in footnote 1 of the IMT Charter, that provided notice to the U.K. government of adherence pursuant to article 5 of the IMT Charter. IMT Statute, supra note 155, at $280 \mathrm{n}$.1. For the ICTY and ICTR, the "relevant collection of states" was the Security Council acting pursuant to Chapter VII of the U.N. Charter. For hybrid tribunals created in coordination with the United Nations, the "relevant collection of states" is the Security Council or General Assembly, depending on the tribunal, and the applicable domestic authority. For the ICC, the "relevant collection of states" refers to the states-party to the Rome Statute. 
tribunal being established to exercise prescriptive jurisdiction because there is no inefficiency to correct in relation to this category. An early articulation in contemporary international law of the character of prescriptive jurisdiction is offered in the Lotus majority opinion of the Permanent Court of International Justice. Specifically, the observation that "every State remains free to adopt the principles which it regards as best and most suitable"212 is a succinct articulation of prescriptive jurisdiction.

In the present application, it is the relevant collection of states that is acting to "adopt the principles which" the states regard "as best and most suitable." As the Restatement (Fourth) of Foreign Relations Law explains, "Customary international law permits exercises of prescriptive jurisdiction if there is a genuine connection between the subject of the regulation and the state seeking to regulate .... In the case of universal jurisdiction, the genuine connection rests on the universal concern of states in suppressing certain offenses." ${ }^{\text {"13 }}$ In the context of establishing international criminal tribunals, the relevant states exercise prescriptive jurisdiction collectively, and the "genuine connection" is articulated in the aspiration to end impunity for perpetrators of grave breaches and serious violations of international law. There is no inherent inefficiency that needs to be addressed as the relevant collection of states exercise prescriptive jurisdiction. The charter promulgated to establish a particular tribunal constitutes the prescription of law the tribunal is to apply. By establishing this prescription, the relevant collection of states "designates" the applicable law.

While there is no constraint prohibiting the relevant collection of states from freely exercising prescriptive jurisdiction, the fundamental inefficiency described above involving international law frustrates the exercise of adjudicative and enforcement jurisdiction. Turning again to Lotus, the majority opinion notes that a state "should not overstep the limits which international law places upon its jurisdiction." ${ }^{214}$ In the present application, the preeminent value placed on territorial integrity constitutes the central "limit" that frustrates the effort to adjudicate offenses and enforce judgments. ${ }^{215}$ It is the inefficiency inherent in

212. The Case of the S.S. "Lotus" (Fr. v. Turk.), Collection of Judgments, 1927 PCIJ (ser. A) No. 10, at 19 (Sept. 7) [hereinafter Lotus].

213. RESTATEMENT (FOURTH) OF FOREIGN RELATIONS LAW, supra note $203, \S 407$.

214. Lotus, supra note 212 , at 19.

215. Regarding the exercise of enforcement jurisdiction, it is helpful to further divide this category into pre-adjudicative and post-adjudicative subcategories. Both subcategories represent a separate inefficiency in intemational law. Inefficiencies inherent in pre-adjudicative enforcement are addressed primarily by extradition agreements, provisions in multilateral 
these two categories of jurisdiction, adjudicative and enforcement, that needs to be addressed since there is no state able and willing to take the action that would be needed to achieve the aspiration of ending impunity. International criminal tribunals are the tools created by the relevant collection of states to correct this inefficiency, and the method of employing these tools is to "extend" adjudicative and enforcement jurisdiction from the collective of states to the tribunals thus established.

In describing this process, the term "extend" is carefully and deliberately selected rather than "delegate" because of the expectation of tribunal independence detailed above. The terms may appear substantially similar at first glance, but it is a distinction with a difference. Describing this process using the term "extend" is most appropriate given the independent, quasi-state role international criminal tribunals perform in the exercise of adjudicative and (post-adjudicative) enforcement jurisdiction. As long as the relevant collection of states does not substantially alter or revoke the establishing statute, the tribunal is expected to employ these two categories of jurisdiction independently, in the same manner as a state. It is exclusively in these two specific categories of jurisdiction, then, that the tribunals can be considered to possess a degree of comity with states.

Put another way, in the exercise of adjudicative and enforcement jurisdiction, international criminal tribunals are conceptually an extension of the relevant collection of states. Describing this relationship as a "delegation" in line with the principal-agent model implies a superior-subordinate relationship in which the principal has discretion to direct and, when necessary, to correct the conduct of the agent. This description is conceptually problematic because the directing and, when necessary, correcting by states occurs in relation to prescriptive jurisdiction when the relevant collection of states designates or modifies the formulation of the law to be applied by the applicable tribunal. A delegation inherent in a principal-agent relationship entails a degree of control that belies the

treaties permitting so-called "universal" jurisdiction, and cooperation provisions such as those found in the Rome Statute. While these agreements and provisions do not completely mitigate the inefficiency created by the value of territorial integrity, the provisions attempt to achieve an acceptable balance between separate values such as sovereignty and political independence. The inefficiency inherent in post-adjudicative enforcement is less pronounced, assuming that some pre-enforcement mechanism has secured the presence of the defendant before the relevant international tribunal. Post-adjudicative enforcement inefficiency is addressed by cooperation agreements with states allowing states to effectuate incarceration penalties that result from the judicial proceeding adjudicated by the tribunal. 
independence expected of tribunals when exercising adjudicative and enforcement jurisdiction.

Consolidating these two distinct functions-designate and extendrequires conceptualizing the statutes of international criminal tribunals as separate and distinct from judicial opinions that emerge from the tribunals. The statutes constitute circumstantial, if not direct, evidence of state practice because the relevant collection of states is acting to prescribe, or designate, the law to be applied by the applicable tribunal. The principle of legality, or nullum crimen sine lege, requires the relevant collection of states to articulate and endorse the customary law that binds all states universally. The judicial decisions that flow from tribunals, however, are a necessary function of exercising the adjudicative and enforcement jurisdiction extended to the tribunals. Explicitly or implicitly ascribing lawmaking authority to judicial opinions of international criminal tribunals is problematic because prescriptive jurisdiction was not extended or otherwise transferred from the relevant collection of states to the applicable tribunal in the first instance.

Applying this designate and extend model to the progression of statutes of international criminal and selected hybrid tribunals and separately to the judicial opinions that flow therefrom reveals the gradual yet steady expansion and solidification of what has become accepted as customary international law in the present context. This application confirms the status of prescriptions reflected in statutes as primary, or at least near primary, sources of customary international law, as the relevant collection of states "designates" the law to be applied by the tribunal being established. Similarly, judicial opinions from international criminal tribunals are confirmed as subsidiary sources of law, as the tribunals are merely exercising the extent of the adjudicative and enforcement jurisdiction the relevant collection of states "extends" to the tribunals. In this progression of discernible prescriptions of customary international law, the Rome Statute emerges as the exemplar formulation that constitutes a paradigm shift in the understanding of what is widely accepted as customary.

2. The Evolution of Statutes as Prescriptions in the Designate and Extend Model

Prior to the Rome Statute, the substantive war crimes provisions of international criminal statutes followed the lead of the IMT and incorporated formulations involving means and methods of warfare from 
the Hague Regulations. ${ }^{216}$ By the time the ICTY statute was established in 1993, Additional Protocol I had been in force for over just over fifteen years. The text of AP I substantially expands on the "undefended towns" expression of the distinction rule articulated in Hague, IV of 1907 by prohibiting, among similar conduct, making the "civilian population as such, as well as individual civilians ... the object of attack." ${ }^{217}$ Although AP I had entered into force over fifteen years prior and the treaty offers significantly more detail in relation to the distinction rule than Hague, IV, the group of experts tasked to draft the text of the ICTY statute eschewed AP I as a source from which to draw articulations of customary international law that would be included in the ICTY statute.

The reluctance to draw explicitly from AP I as a primary source for the ICTY statute was founded upon the legality principle. As Virginia Morris and Michael P. Scharf observe, even fifteen years after entering into force, AP I "could not be said to be in all essential respects beyond doubt customary law either on the basis of virtually universal acceptance or an authoritative pronouncement on behalf of the international community." ${ }^{18}$ The standard for the nullum crimen sine lege requirement articulated by the Secretary-General in the report submitted to the Security Council advocates that the ICTY "should apply rules of international humanitarian law which are beyond any doubt part of customary law." 119 According to a scholarly observation that was a contemporary of the court, the judges of the IMT, "considered that the Hague Convention on land warfare was declaratory of customary international law binding all the belligerents." ${ }^{220}$ The fledgling UN Security

216. Compare Statute of the International Criminal Tribunal for the Former Yugoslavia art. 3 (c), https://www.icty.org/x/file/Legal\%20Library/Statute/statute_sept09_en.pdf (establishing the offense of "attack, or bombardment, by whatever means, of undefended towns, villages, dwellings, or buildings"), with IMT Statute, supra note 155, art. 6(b) (establishing the offense of "wanton destruction of cities, towns or villages, or devastation not justified by military necessity"), and Convention Respecting the Laws and Customs of War on Land, Annex, art. 25, Oct. 18, 1907, 6 U.S.T. 3616 (prohibiting "attack or bombardment by whatever means, of towns, villages, dwellings, or buildings which are undefended") [hereinafter Hague, IV].

217. AP I, supra note 48 , art. $51(2)$.

218. Virginia Morris \& Michael P. Scharf, An Insider's Guide to the International Criminal Tribunal for the Former Yugoslavia: A Documentary History and Analysis 62 n.207 (1995).

219. U.N. Secretary-General, Report of the Secretary-General Pursuant to Paragraph 2 of Security Council Resolution 808, II 34, U.N. Doc. S/25704 (May 3, 1993) [hereinafter Secretary-General ICTY Report].

220. Quincy Wright, The Law of the Nuremberg Trial, 41 AM. J. INT'L L., 38, 60 (Jan. 1947) (citing the IMT judgment of Oct. 1, 1946, reprinted in the same volume of AJIL from Pp. 172-333 at 248, 
Council endorsed the legal basis of the International Military Tribunal in 1946, ${ }^{221}$ further solidifying the status of Hague, IV as an articulation of customary international law. By 1993, Hague, IV, along with the 1949 Geneva Conventions and the Genocide Convention, were sufficiently "beyond any doubt part of customary law" such that the ICTY statute could draw directly from them. AP I, at the time, did not qualify.

While AP I was eschewed as a standalone source of customary law for the ICTY statute, ${ }^{222}$ state delegates involved in the Rome process just five years later drew heavily on AP I for the substantive offenses reflected in the Rome Statute. The task of the delegates to Rome in 1998 was similar to that of the Security Council in establishing the ICTY statute in 1993: to design a formulation of existing customary law that would be applied by the tribunal being established. However, delegates of the 160 states that met to deliberate the text of what would become known as the Rome Statute did so for the express purpose of establishing a permanent, standing international criminal tribunal that does not rely on an assorted collection of treaties from which to extrapolate articulations of customary international law. ${ }^{223}$ Moreover, the state representatives were engaged in the deliberations for the Rome Statute with the knowledge that the final text would become an issue of direct domestic political importance when the treaty was ultimately presented to the applicable national lawmaking process of each delegation for approval and ratification. ${ }^{24}$ These factors operate to establish the prescription of law reflected in the Rome Statute as an exceedingly probative proxy for state practice. In the Rome Statute, significant

which observes that "by 1939 these rules laid down in the Convention were recognized by all civilized nations, and were regarded as being declaratory of the laws and customs of war").

221. See G.A. Res. 95(I), Affirmation of the Principles of International Law Recognized by the Charter of the Nuremberg Tribunal (Dec. 11, 1946), https://legal.un.org/avl/pdf/ha/ga_95-I/ ga_95-I_Ph_e.pdf.

222. The establishing statute for the ICTR, as a contemporary of the ICTY statute, can be included in this observation as well. The similarity in subject matter can be summarized by the observation of the Secretary-General that the ICTR constitutes "an adaptation of the statute of the Yugoslav Tribunal to the circumstances of Rwanda." U.N. Secretary-General, Report of the SecretaryGeneral Pursuant to Paragraph 5 of Security Council Resolution 955, II 7, U.N. Doc. S/1995/134 (Feb. 13, 1995).

223. See Darryl Robinson \& Herman von Hebel, War Crimes in Internal Conflicts: Article 8 of The ICC Statute, 2 Y.B. INT'L HUMANITARIAN L. 193, 194, 208 (1999).

224. See, e.g., II Rome Conference Official Records, supra note 122, at 280 (summary of statement by U.S. representative, observing that "the effectiveness of the Court would largely be judged by the willingness of a significant number of States to join in the treaty and assist the Court in bringing individuals to justice" and that the tribunal's "membership would be limited if it sought to overreach established customary international law or set aside national judicial principles"). 
portions of AP I for the first time joined longstanding treaties such as Hague, IV, the 1949 Geneva Conventions, and the Genocide Convention as sources from which to draw formulations of customary law.

The extent of the persuasiveness of the text of the Rome Statute as a prescription of customary international law is revealed by comparing the content of the statute for the ICTY with that for the Special Court for Sierra Leone (SCSL). While the ICTY statute shuns AP I in favor of longstanding predecessors, the statute for the SCSL includes the offense of "[i]ntentionally directing attacks against the civilian population as such or against individual civilians not taking direct part in hostilities" among the list of war crimes. ${ }^{225}$ Not only is this provision extrapolated directly from the Rome Statute, ${ }^{226}$ which in turn is based the distinction rule reflected in AP I, ${ }^{227}$ but it is the first tribunal statute established under the auspices of the United Nations ${ }^{228}$ to include the mens rea requirement of "intentional."

With the exemplar text of the Rome Statute recently adopted, the process of establishing the prescription for a tribunal to apply became relegated to an afterthought. When the Security Council approved creation of the SCSL by adopting UNSCR 1315 in August 2000, the Rome Statute had only existed for two years and only fourteen states had ratified the treaty. ${ }^{29}$ Nonetheless, rather than approving the text of the SCSL statute directly, the Security Council merely recommends a list of

225. Statute of the Special Court for Sierra Leone, art. 4(a), Aug. 14, 2000, 2178 U.N.T.S. 145.

226. See Rome Statute, supra note 25 , arts. 8(b) (i), 8(e) (i).

227. See AP I, supra note 48, art. 51(2) (establishing that "[t] he civilian population as such, as well as individual civilians, shall not be the object of attack").

228. Two months before the SCSL was established, the UNTAET adopted a regulation establishing panels with exclusive jurisdiction over serious criminal offenses, and this regulation incorporates a similar war crime formulation that is identical to a Rome Statute provision, which in turn is based on the distinction rule articulated in AP I. See U.N. Transitional Administration in East Timor, Regulation no. 2000/15, U.N. Doc. UNTAET/REG/2000/15 (June 6, 2000), www. legal-tools.org/doc/c082f8/pdf. On the establishment of panels with exclusive jurisdiction over serious criminal offences, see $i d$. art. $6(1)(\mathrm{b})$. Although this regulation is an additional indication of the centrality of the Rome Statute as a prescription of customary international law, the present inquiry does not focus on this UNTAET regulation because it was adopted by the Special Representative of the Secretary-General rather than by a relevant collection of states. As such, this regulation, while informative, is of limited value to the present inquiry.

229. Security Council Resolution 1315 was adopted on Aug. 14, 2000, and according to the chronological listing of state parties that is published by the ICC Assembly of State Parties (ASP), fourteen states had acceded to or ratified the Rome Statute on that date (Mali would become the 15th member two days later). See ICC ASP, States Parties - Chronological list, https://asp.icc-cpi. int/en_menus/asp/states\%20parties/Pages/states\%20parties\%20_\%20chronological\%20list.aspx (last visited Oct. 22, 2020). 
the offenses to be included ${ }^{230}$ and requests that the Secretary-General report back to the Security Council after the establishing resolution is implemented. ${ }^{231}$

The record of the Security Council meeting at which UNSCR 1315 was adopted and the SCSL established indicates that the resolution was unanimously approved by the Council in a matter of ten minutes, with no member of the Council speaking other than the president, who essentially announced the item on the agenda and called for a vote. ${ }^{232}$ The mere existence of the Rome Statute and the process that had led to its formation relegated the matter of establishing subject matter jurisdiction for the SCSL to an afterthought to be entrusted to the Secretary-General to sort out. Such is the procedural significance of the Rome Statute as an authoritative prescription of relevant international law.

3. Consolidating the Designate and Extend Model: Distinguishing Between Statutes and Judicial Opinions

With the prescriptions reflected in statutes of international criminal tribunals established as proxies for state practice, judicial opinions that flow from the tribunals can reenter the present inquiry. Like other subsidiary sources of customary law, these judicial opinions can provide an informative indication of the content of international law. Jurisprudence from the ICTY was extraordinarily influential in the deliberations that led to the creation of the Rome Statute of the ICC, for example, as delegates often brought "copies of key [ICTY] decisions with their materials for the negotiations" that led to adoption of the Rome Statute. ${ }^{233}$ However, the decisions of international criminal tribunals do not constitute an independent primary source of law.

In establishing the prescription to be applied by the applicable tribunal, even the relevant collection of states does not possess independent legislative authority. Rather, the task of the relevant states is to "designate" the law as it exists from a survey of general state practice. ${ }^{234}$ Tracking the development of the statutes over time reveals the

230. S.C. Res. 1315, pmbl. (Aug. 14, 2000).

231. Id. II 6 .

232. See U.N. SCOR, 55th Sess., 4186th mtg., U.N. Doc. S/PV.4186 (Aug. 14, 2000).

233. Danner, supra note 179 , at 35 .

234. See, e.g., Secretary-General ICTY Report, supra note 219, If 29 (emphasizing that "the Security Council would not be creating or purporting to "legislate" applicable customary international law and that, instead, the ICTY "would have the task of applying existing" international law (emphasis added)). 
progression of what is widely accepted as customary law. The statute for the ICTY lacks much of the detail of its ICC counterpart, and this scarcity of detail can be attributed to the concern that getting bogged down in details during deliberations would threaten to derail the entire project. ${ }^{235}$ With much of the specific detail omitted from the statute in favor of expediency and consensus in the Security Council, judges of the ICTYwere later left to fill in the gaps.

The "international case-law" that emanated from the ICTY was available to and considered by the delegates that participated in the Rome process. Although it was suggested during preparations for the Rome Conference that the statute for the ICC might follow the example of the ICTY statute and leave judges to devise much of the substantive detail to be applied by the tribunal, this approach was rejected by the delegates that participated in the Rome process. ${ }^{236}$ While consulting jurisprudence from predecessor tribunals, including the ICTY, and resolving to articulate detailed prescriptions for the judges of the ICC to apply, delegates from the 160 states that participated in the Rome process devised a thorough and detailed statute that would set the example for later similar endeavors to follow. The Rome Statute, then, represents a pristine proxy for general state practice and, as such, constitutes an exemplar customary articulation involving prescriptions for grave breaches and serious violations of international law.

The endeavor to rely on judicial opinions as direct evidence of controlling customary international law is problematic because this degree of authority was not vested in tribunals ab initio. It is not up to the future judges of the ICC to bring the Rome Statute in line with jurisprudence from the ICTY and adopt the mens rea formulations derived by the judges of the ICTY, as Cassese ${ }^{237}$ and Dörmann ${ }^{238}$ suggest. Nor is it incumbent upon states to implement formulations derived from ICTY judicial opinions in order to comply with customary international law,

235. As the delegate from Spain observed during the deliberations that led to the creation of the ICTY, "the goal of restoring peace in the territory of the former Yugoslavia requires prompt action, which might have been compromised through a prolonged and detailed discussion of a Statute which satisfies the fundamental prerequisites for ensuring the achievement of that goal." S/PV.3217, supra note 190, at 39.

236. See Clark, supra note 13, at 298 (recalling that the delegates at the Rome Conference "set forth on an "arduous task of comparative criminal law synthesis" rather than, as the "Updated Siracusa Draft" indicated to be the alternative, leaving the establishing statute "to delegate to the ICT the power to promulgate, before it starts any proceedings and in accordance with the principles contained in the Statute, whatever additional norms are needed").

237. See Cassese, supra note 169.

238. See Dörmann, supra note 171. 
as suggested by scholars ${ }^{239}$ and advocacy organizations such as Human Rights Watch. ${ }^{240}$ Relying exclusively on judicial opinions from "international case-law" to support a purported rule of customary international law, as does the central recklessness assertion reflected in Rule 156 of the ICRC CIHL study, is similarly inadequate because it assigns a degree of authority to judicial decisions that does not exist, conceptually or in practice.

Salient prescriptions of customary international law are reflected in the progression of the statutes for international criminal tribunals, with the Rome Statute being at the apex of this progression. Judicial opinions that emanate from the various tribunals simply represent a necessary function of exercising the adjudicative and enforcement jurisdiction that is extended by the relevant collection of states to the applicable tribunal in order to address discernible deficiencies created by operation of international law. As applying the designate and extend model confirms, it is not the case that "international judicial lawmaking may be the truth of international politics that cannot be named," as Allison Danner suggests. ${ }^{241}$ Rather, the popular narrative of "international judicial lawmaking" is simply not the truth at all.

\section{Concluding Reflections}

Two separate unsettled matters that are central to the theory and practice of public international law are addressed by the dual inquiries above, with the goal of bringing a degree of clarity to both issues of concern. Regarding the substantive aspect of the recklessness assertion, the issue of whether "international case-law" actually does establish that recklessness is included on the spectrum of mens rea for war crimes, the inquiry conducted in Part One concludes that the reality is rather more nuanced than the prevailing perspective supports. Jurisprudence of international criminal tribunals does support the recklessness assertion, but only in limited, identifiable circumstances. The assertion that recklessness is sufficient in a general targeting context, as the prevailing narrative suggests, is not supported by a careful and thorough assessment of "international case-law."

Regarding the procedural aspect of the recklessness assertion, the issue of whether "international case-law" can be utilized as an independent, authoritative primary source of customary international law,

239. See, e.g., Haque, supra note 7; Knuckey, Parrin \& Nimmala, supra note 202.

240. See Letter from Sarah Margon, supra note 1, at 2; Human Rights WATch reports, supra text accompanying note 4 .

241. Danner, supra note 179 , at 47 (emphasis added). 
the inquiry conducted in Part Two once again demonstrates that the conclusion is more complex than the prevailing principal-agent model suggests. The designate and extend model described in Part Two accounts for the inefficiencies in international law that international criminal tribunals are created to address and adopts a more nuanced approach to the types of jurisdiction exercised by states. The examination in Part Two demonstrates that statutes of the tribunals constitute prescriptive jurisdiction exercised as the relevant collection of states "designate" the law to be applied by the applicable tribunal, while judicial decisions represent the exercise of the adjudicative and enforcement jurisdiction "extended" to the tribunal by the relevant collection of states. Pursuant to the designate and extend model thus described, the statutes represent primary sources as proxies to state practice, while judicial decisions are confirmed to be subsidiary sources of law.

Turning first to the substantive inquiry from Part One, the conclusion that recklessness is only included in the spectrum of mens rea applicable for war crimes in limited circumstances is consistent with the theory and practice of the conduct of hostilities. The detainee abuse context, consistent with the ICTY Delalic line of cases, is conceptually and practically distinct from the general targeting context, consistent with the Galic line. The presumption of necessity and the knowledge environment in the detainee context are not compatible with the general targeting context. Setting aside the questionable recklessness assertion in the detainee abuse context, the direct analogy between the detention and targeting contexts is conceptually and factually inadequate.

In the general targeting context, focusing on the risk of a proscribed outcome, as does the prevailing recklessness assertion, distorts the distinction rule upon which the relevant war crime is based. Based on the nature of targeting in armed conflict, an attacker is aware of a risk that civilian persons or objects will be injured or damaged before engaging in nearly every attack. To extend recklessness a half-step further to include the related concept of dolus eventualis, the attacker can be inferred to reconcile herself with that potential outcome before engaging in nearly every attack. Adopting this mens rea formulation distorts the distinction rule upon which the applicable war crime is founded by presuming culpability based on the outcome of the attack. If the ostensible requirement is simply that an attacker is aware of the risk of incidental damage and it is factually true that the attacker is aware of such a risk before nearly every attack, then any attack that results in incidental damage presumptively qualifies as a war crime.

This recklessness formulation distorts the conduct on which the applicable war crime-making civilian persons or objects the object of 
attack-is founded. It is illogical to conclude that the distinction rule can be violated based solely on an awareness of the risk that civilians may be injured or killed in an attack, especially because that risk applies to nearly every targeting scenario. Civilian persons or objects cannot be said to be the "object of attack" if the attacker does not at least have knowledge that the person or object being attacked qualifies for civilian status.

What scholars, advocates, and relevant judicial opinions of international criminal tribunals seem to be attempting to accomplish by purporting to include recklessness on the spectrum of mens rea for war crimes is developing an objective process by which to evaluate what is, by design, an inherently subjective standard. While this is a laudable aspiration, purporting to expand the relevant mental element to include recklessness is not actually required to achieve the desired outcome. The factual understanding that develops when assessing the circumstances known to an attacker prior to the attack can lead to an objective deduction that refutes the subjective claim of the defendant that she was not aware of the civilian nature of the person or object attacked. This endeavor occurs in the ICTY Galic trial chamber decision that establishes the recklessness line of cases involving the general targeting context.

In Galic, the defendant directed a sustained shelling and sniping campaign that indiscriminately targeted the civilian population of Sarajevo. The factual details ascertained by the trier of fact are adequate to objectively repudiate the subjective assertion that the defendant did not violate the distinction rule and thereby commit war crimes. These facts are sufficient to at least demonstrate knowledge in Galic, and the risk-based recklessness formulation from the ICRC AP I Commentary that is accepted but not applied by Galić and establishes this line of recklessness cases for the tribunal is as factually superfluous as it is conceptually problematic.

There are at least two other uses for the term "reckless" in scholarship involving mens rea and war crimes, but these interpretations do not appear to apply the term as it should be utilized in a valid legal analysis. One such use of "recklessness" is akin to a colloquial definition of the term. To borrow from the Merriam-Webster Dictionary as an example, the definition of "reckless" is "marked by lack of proper caution" or "careless of consequences." 242 This definition is rather more imprecise than the notion of taking action after reconciling oneself with a

242. Reckless, MERRIAM-WEBSTER, https://www.merriam-webster.com/dictionary/reckless (last visited Oct. 11, 2020). 
prohibited result, which constitutes a standard formulation of the concept of dolus eventualis. ${ }^{243}$ The informal, colloquial application of the term "recklessness" is utilized, by way of illustration, by a former representative of Amnesty International when she refers to the factual record of the attack on the MSF trauma center and observes, "[t]wenty-nine minutes of bombing a hospital and no one notices that the wrong building is being bombed - if that's not recklessness, I don't know what is." 244 This colloquial usage does not resemble the term "reckless" as it is typically used as a legal term of art, but this rather more informal meaning is often employed even when purporting to engage in a legal analysis of whether a war crime was committed.

Similarly, the term "reckless" is sometimes erroneously utilized in an ostensive war crimes analysis to evaluate whether an attacker "should have known" of a particular factual condition before engaging in an attack. For example, a Human Rights Watch report examining the conduct of hostilities in the current conflict in Yemen describes the circumstances of an attack that resulted in civilian casualties in 2016 that was caused by inaccurate information related to the target of the airstrike. In the analysis, the report asserts that "[r]egardless of the faulty intelligence, coalition forces, both in the Yemen air operations center and in Riyadh, either knew or should have known that any attack on the hall would result in massive civilian casualties." 245 This account of the factual circumstances the personnel directly involved in or otherwise responsible for the airstrike purportedly "should have known" before the attack is utilized in support of the assertion that the "strike was an unlawfully indiscriminate or disproportionate attack on civilians and civilian objects in violation of the laws of war" and that the personnel "involved should be criminally investigated for war crimes."246

This assertion, in turn, is supported by a mens rea formulation in the report suggesting that "[d]eliberate, indiscriminate, or disproportionate attacks on civilians and civilian objects are serious violations of the laws of war" that " $[w]$ hen committed by an individual with criminal

243. See BADAR, supra note 14.

244. Jessica Schulberg \& Sophia Jones, U.S. Military Investigates And Finds Itself Not Guilty Of War Crimes In Afghan Hospital Bombing, HufFington POST (Apr. 29, 2016), https://www.huffingtonpost. ca/entry/us-not-guilty-war-crimes-kunduz-hospital_n_57236ddfe4b0b49df6ab0ada?ri18n=true.

245. Human Rights Watch, Hiding Behind the Coalition: Fallure to Credibly Investigate and PROvide REDRESS FOR UNLAwFUl ATTACKS IN YEMEN (Aug. 24, 2018), https://www.hrw.org/report/ 2018/08/24/hiding-behind-coalition/failure-credibly-investigate-and-provide-redress-unlawful\#_ftn89 (emphasis added).

246. Id. 
intent - that is, intentionally or recklessly - they are war crimes."247 The contention that an attack can be characterized as "reckless," and therefore as a war crime, based on an assertion regarding information the attacker should have known before engaging in the attack constitutes a fundamental misapplication of the requirement to evaluate LOAC compliance based on information that was reasonably available to the relevant personnel at the time of the attack. ${ }^{248}$ Like the colloquial usage described above, this "should have known" meaning does not faithfully apply the formal dolus eventualis construct developed by the already questionable jurisprudence of international criminal tribunals the usages purportedly apply.

In a broader context, the endeavor of international tribunals to draw directly from the constellation of comparative domestic criminal law mens rea formulations to derive a general mental element for war crimes constitutes a fool's errand at the outset. Domestic criminal law frameworks are devised to promote social order where the presumption is that a state exercises a monopoly on the use of force and individual persons do not need to use force unless a lawful exception applies. This raison d'être of domestic criminal law is not compatible with an armed conflict targeting scenario in which the attacker is required to use force out of necessity to accomplish the role of combatant or fighter.

While the conceptual diversity between the law of armed conflict and domestic criminal law applications may not be perceptible in some contexts, in others the theoretical foundations of the two are fundamentally incompatible. An armed conflict detention context is conceptually similar to a domestic law enforcement or general domestic criminal law context in large part because the cluster concept of necessity ${ }^{249}$ operates in a similar fashion across all three fields. Drawing analogies from a survey of national jurisdictions to inform the contours of the Geneva stream of the law of armed conflict, then, can be a constructive exercise.

This is not the case in the targeting context. The cluster concept of necessity functions differently in the Hague stream of the law of armed conflict than in the Geneva stream or in domestic contexts. A combatant or other fighter is required and expected to use force to achieve a defined military purpose, and in the targeting context a combatant or fighter operates in a comparatively information poor environment that

247. Id. (emphasis added) (citing CIHL Study).

248. See, e.g., United Kingdom of Great Britain and Northern Ireland, Declaration and Reservations for AP I, Re: Article 52, supranote 73.

249. See OHLIN \& MAY, supra note 64. 
will result in a significant risk that a mistake of fact will occur. As the ICTY Blaskić appeals chamber opinion notes while engaging in a survey of national jurisdictions and citing an opinion from the High Court in Australia, "[a] person who does an act causing death knowing that it is probable that the act will cause death or grievous bodily harm is . . . guilty of murder." ${ }^{250}$ In an armed conflict targeting context, nearly every attack is conducted in the knowledge that death or grievous bodily harm will occur-this is by design and out of necessity. Attempting to extrapolate from a comparison of varied domestic criminal law mens rea formulations an authoritative mental element applicable to the Hague stream of the law of armed conflict constitutes a category error that renders the articulation conceptually and legally problematic.

If national jurisdictions are to be surveyed to develop a coherent interpretation of the mental element that is valid in the targeting context, domestic criminal codes of general application should not be the focus. Rather, the inquiry should be centered on legislation, regulations, judicial practice, and other military disciplinary measures involved in adjudicating or otherwise addressing attacks that result in unintended outcomes such as civilian casualties or fratricide in armed conflict. While such a comparative examination is beyond the scope of this Article, ongoing research conducted by the present author surveying over 130 states supports the conclusion that recklessness is not included in the spectrum of mens rea for war crimes in the targeting context.

Although this conclusion is at odds with the prevalent recklessness assertion, it should be expected based on the assessment of the Rome Statute conducted in Part Two and on the process that created the treaty. As Roger Clark notes in separate observations about his experience as a delegate in the Rome process, " $[d]$ olus eventualis fell out of the written discourse before" the Rome Conference ${ }^{251}$ and delegates "were generally uncomfortable with liability based on recklessness or its civil law (near) counterpart dolus eventualis." 252 Given the nature of the process that created the Rome Statute and the number of states that have ratified the treaty, one would expect state practice in adjudicating offenses in the specialized context of targeting mishaps in armed conflict to be largely consistent with the prescriptions of the Rome Statute,

250. Prosecutor v. Blaškić, Case No. IT-95-14-A, Appeals Judgment, II 37 (Int'l Crim. Trib. for the Former Yugoslavia July 29, 2004) (citing $R v$ Crabbe (1985) 58 ALR 417 [156 CLR 464], 470 (Austl.)).

251. Clark, supra note 13 , at 301.

252. Clark, supra note 115 , at 525. 
notwithstanding the vast comparative diversity that exists in general domestic criminal practice.

Although canvassing general domestic criminal practice to divine definitions for specialized concepts such as the mental element applicable for the war crime of making civilians the object of attack may have constituted a fool's errand at the ad hoc tribunals, it was an errand of necessity. Such surveys may have been directed at the incorrect category of comparative domestic practice in certain applications, but judges of the ad hoc tribunals were required to develop much of the granular detail since the Security Council prioritized consensus and expediency over deliberating minutiae. This is not the case for the extensive and detailed exercise of prescriptive jurisdiction reflected in the Rome Statute.

Informed by the practice of predecessor tribunals and aware that creation of a permanent international criminal tribunal may subject nationals of their own states to prosecution before the tribunal, delegates deliberated and approved a text containing detailed prescriptions of the law to be applied by the ICC. The Rome Statute is not inconsistent with prior "precedent" established by jurisprudence of the ad hoc tribunals as many narratives involving the recklessness assertion suggest. This perspective incorrectly confers "lawmaking" authority that was not extended by the relevant collection of states to judges of international criminal tribunals. In the evolution of prescriptions of international criminal law, the Rome Statute is the apex designation. Judicial opinions of predecessor tribunals that are contrary to the Rome Statute are inconsistent with customary international law, not the other way around.

As for the ICRC articulation that provides analytical structure for the present inquiry, this formulation fails on substantive and procedural grounds. "International case-law" does indicate that recklessness is included on the mens rea spectrum for war crimes, but the applicable contexts are far more limited than the general observation from Rule 156 of the ICRC CIHL study supports. To the extent that the assertion rests solely on judicial opinions (in this case, one) of international criminal tribunals for authority, it fails procedurally as a purported formulation of customary international law as well.

This assessment of the substantive and procedural deficiency of the ICRC recklessness assertion is not affected by the noticeably equivocal language employed by the articulation. If it were extracted from its present context, the observation that "international case-law" has indicated that recklessness is included on the spectrum of mens rea for war crimes is supportable, with significant limitations. However, this 
observation is included as a "rule" of what purports to be a plenary survey of customary international law involving armed conflict. In this context, the assertion is not treated as a benign, passing observation that "international case-law has indicated" that recklessness is sufficient. Instead, it is treated as evidence of a customary rule that recklessness is included in general on the spectrum of mens rea for war crimes by schol$\operatorname{ars}^{253}$ and advocacy groups ${ }^{254}$ alike.

To constitute a valid formulation of customary international law, the recklessness assertion would need to present an accurate distillation of the law that is founded upon authoritative sources. Instead, the ICRC "rule" upon which the recklessness assertion is commonly based provides an incomplete and misleading characterization of "international case-law" that is derived from subsidiary sources of customary law while ignoring contrary "indications" from more authoritative sources. By expressing a rule of general applicability without extensive limitations and by relying on formulations derived from references such as opinions of international tribunals that are confirmed to be subsidiary sources by application of the designate and extend model, Rule 156 of the ICRC CIHL study and similar assertions that recklessness is included on the spectrum of mens rea for war crimes as a matter of customary international law are found wanting.

253. See CASEY-MASLen \& Haines, supra note 6; Diane Bernabei \& Beth Van Schaack, State Dept. Inspector General Report: A Troubling Message on Arms Sales, Just SECuRITY (Aug. 26, 2020), https:// www.justsecurity.org/72188/state-dept-inspector-general-linick-saudi-arms-sales (citing only to ICRC CIHL Rule 156 as a reference establishing the definition for violations of "the laws of war [and] the prohibition on war crimes" while describing a perceived "clear and dominant pattern that has emerged around the [Saudi-led] Coalition's behavior in the war in Yemen - the reckless, indiscriminate, or intentional targeting of civilians" (emphasis added)); Ryan Goodman, Explainer: What Mental State is Required to Commit a War Cnime?, JUST SECURITY (Sept. 1, 2016), https://www.justsecurity.org/32644/explainer-mental-state-required-commit-war-crime

(describing the author's perspective regarding the components of the war crime of "willful killing" while citing to an ICRC Website containing, among other references, the ICRC Commentary to AP I and asserting that violations of the LOAC distinction and proportionality rules "include recklessness, for example, when the attacker consciously disregards a substantial and unjustifiable risk of the harm to civilians and civilian objects").

254. See Letter from Sarah Margon, Washington Dir., Human Rights Watch, to Ashton Carter, supra note 1; HUMAN RIGHTS WATCH, supra note 4. 